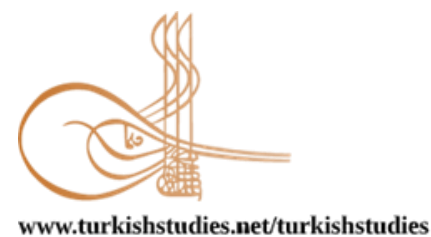

Turkish Studies

\title{
Covid-19 Salgını Sürecinde Siyasi Parti Liderlerinin Twitter Mesajlarının Analizi
}

\author{
Analysis of Twitter Messages of Political Party Leaders in the Covid-19 Pandemic Process
}

\author{
Çiğdem Tosun*
}

\begin{abstract}
Covid-19 pandemic appeared in China at the end of 2019 and affected the whole world. In this process, political leaders' policies and discourses in the fight against the Covid-19 pandemic were observed carefully. The leaders conveyed messages on Twitter. The aim of the study is to determine how political party leaders tried to manage the process, set the agenda and influence public opinion using Twitter. In this study, the discourses shared by the political party leaders on Twitter during the Covid-19 pandemic process were examined. In Turkey the first Covid-19 case was seen on March 11 and normalization steps were taken on June 1, so the tweets by leaders between March 11 and June 1 were used for the purposes of this study. Tweets posted by four political party leaders, namely Devlet Bahçeli, Kemal Kılıçdaroğlu, Meral Akșener and Recep Tayyip Erdoğan were examined in detail. These political figures were chosen as they are the leaders of either the ruling party or the opposition in Turkey. Content analysis and discourse analysis methods were used in the study. When the tweets were examined, it was determined that all leaders expressed the Covid-19 pandemic and the economy. The leaders emphasized the fight against the disease. Since the pandemic affected the economy negatively, the government brought economic support packages to the agenda while the opposition criticized those economic policies. All leaders shared positive and constructive tweets on the establishment of a Scientific Committee, the need for quarantine measures and social distancing as well as the appreciation of the efforts of healthcare workers. Kilıçdaroğlu and Erdoğan stated that they were against the coup in the coup debates. The opposition criticized the government for the freedom of press, aid campaigns by municipalities, law on execution of sentences and postponement of the university exam. While the government supported the National Solidarity Campaign, the opposition criticized the sharing of IBAN numbers on Tv channels. Bahçeli and Akșener shared similar ideas about the importance and current state of agricultural activity in the country. Bahçeli stated that food security should be ensured, and Akşener mentioned the need for the protection of agricultural areas. Bahçeli criticized Akşener's proposal to come together as leaders so that problems could be solved more effectively. Akşener criticized Erdoğan on sending aid abroad. Akșener mentioned on unemployment. Erdogan shared messages about city hospitals.
\end{abstract}

Structured Abstract: Covid-19 pandemic affected Turkey as it did many other countries. Political leaders' policies and discourses in the fight against the Covid-19 pandemic were carefully observed. The leaders conveyed messages on Twitter. Tweets shared by Devlet Bahçeli, Kemal Kılıçdaroğlu, Meral Akşener and Recep Tayyip Erdoğan were analyzed in this study to understand how discourses by political party leaders shared via Twitter influenced the agenda and the public opinion during the Covid-19 pandemic process.

\footnotetext{
* Dr. Gazetecilik

PhD. Journalism

ORCID 0000-0001-9305-1453

cigdemtosun865@gmail.com

Cite as/ Atıf: Tosun, C.. (2020). Covid-19 salgını sürecinde siyasi parti liderlerinin Twitter mesajlarının analizi.

Turkish Studies, 15(6), 893-923. https://dx.doi.org/10.7827/TurkishStudies.45141

Received/Geliş: 10 July/Temmuz 2020

Checked by plagiarism software

Accepted/Kabul: 15 October/Ekim 2020

Published/Yayın: 20 October/Ekim 2020

Copyright $(\mathrm{C}$ MDE, Turkey

CC BY-NC 4.0
} 
Twitter messages of political party leaders for the dates between 11 March and 1 June were analyzed accordingly. The results gave insights into the ways Twitter was utilized by the leaders. Bahçeli, for example, shares messages less frequently on Twitter, but his messages are usually around a specific topic and are made up of a long series of tweets. Kılıçdaroğlu shares his messages on Twitter with shorter sentences and states his messages in the same tweet as that day's celebrations, commemoration and condolences. In this study, tweets by Kılıçdaroğlu were used less frequently than those of other leaders since the above mentioned topics were not included in the scope of the study. Akşener is a leader who uses Twitter most actively and shares critical tweets on many different topics. Erdogan shares a lot of messages on specific topics and mentions on the same topic on different days.

The issues mentioned by the political leaders between 11 March and 1 June were identified as follows: the 3600 additional indicator in the civil servant salary account, justice, informative function of the press, freedom of press, aid campaigns by municipalities, Scientific Committee, provocation caused by the playing of a song in the mosque, Covid-19, Presidential Government System, coup d'état, education, economy, people who cannot retire because they cannot meet the age requirement, racism, resignation of Interior Minister Süleyman Soylu, conflict between power and opposition, law on execution of sentences, unemployment, quarantine, the idea of a Homeland Panel, National Solidarity Campaign, declaration of state of emergency, relations with Russia, healthcare workers, social distancing, city hospitals, agriculture, postponement of the university exam, and provision of aid to countries abroad.

All leaders touched on the Covid-19 pandemic and economy in their tweets. The leaders emphasized the fight against the Covid-19 pandemic and shared positive, constructive messages. While the government offered financial support packages to ease the negative impact of the Pandemic on national economy, the opposition criticized the economic policies. All leaders shared positive and constructive tweets about the Science Committee and healthcare workers as well as quarantine and social distancing measures. Kılıçdaroğlu and Erdoğan stated that they were against the coup d'état when the coup d'état was implied. However, they accused the opposing political view of defending the coup d'état. The opposition condemned the restrictions imposed on the press and opposed law on execution of sentences. The opposition criticized the governor's permit requirement for municipal aid campaigns. When the ruling party announced that the university exam was to be administered earlier, the opposition objected to it. While the government supported the National Solidarity Campaign, the opposition criticized the sharing of IBAN numbers on TV channels. Bahçeli and Akşener shared similar ideas about the importance of agriculture. Bahçeli stated that food security should be ensured, and Akşener emphasized the need for the protection of agricultural areas. However, Bahçeli did not agree with the idea of a Homeland Panel proposed by Akşener. While Bahçeli did not support the resignation of Interior Minister Süleyman Soylu, Akşener thanked Soylu for his resignation. Among all leaders, only Bahçeli expressed the Scientific Committee, the Presidential Government System and the informative function of the press. Only Kılıçdaroğlu questioned that a song was played for provocation inside the mosque. Only Akşener made reference to the 3600 additional indicator, education, unemployment, the declaration of state of emergency, and relations with Russia. Akşener also supported people who could not retire because they could not meet the age requirement. Finally, only Erdogan shared messages about racism and city hospitals.

Political leaders shared in their tweets compromising and constructive messages on issues that had to do with the pandemic. However, they maintained their positions of power and opposition on issues regarding those areas indirectly affected by the pandemic. They expressed this by means of otherization and contradiction. Leaders not only conveyed informative messages regarding the fight against the pandemic, but also stressed the importance of solidarity and unity. Leaders tried to influence the public in line with the opinions of their own parties on the issues of economy, aid campaigns of municipalities, coup d'état, law on execution of sentences, idea of Homeland Panel, National Solidarity Campaign, postponement of the university exam. They attempted to achieve this through political opposition.

Keywords: Politics, leader, discourse, Twitter, Covid-19.

Öz: Covid-19 salgını 2019 yılının sonunda Çin’de ortaya çıkarak tüm dünyayı etkilemiştir. Bu süreçte siyasi liderlerin salgınla mücadelede uygulamaya koydukları politikalar ve söylemler dikkatle takip edilmiştir. Liderler Twitter üzerinden mesajlar vermişlerdir. Bu çalışmanın amacı da Covid-19 salgını sürecinde siyasi parti liderlerinin Twitter'ı nasıl kullanarak süreci yönetmeye, gündemi belirlemeye ve kamuoyunu 
etkilemeye çalışıklarını tespit etmektir. Bu çalışmada Covid-19 salgını sürecinde siyasi parti liderlerinin Twitter'da paylaştıkları söylemleri incelenmiştir. Bu amaçla Türkiye'de ilk vakanın görüldüğü 11 Mart ve normalleşme adımlarının atıldığı 1 Haziran tarihleri arasında paylaştıkları tweetler çalışma kapsamına alınmıştır. Dört siyasi parti liderinin attıkları tweetler çalışmada incelenmiştir. Bu liderler Devlet Bahçeli, Kemal Kılıçdaroğlu, Meral Akşener ve Recep Tayyip Erdoğan'dır. Bu dört liderin seçilmesinin nedeni iktidar ve muhalefet konumunda olmalarıdır. Çalışmada yöntem olarak içerik analizi ve söylem çözümlemesi kullanılmıştır. Tweetler incelendiğinde tüm liderlerin Covid-19 salgını ve ekonomi konusuna değindikleri tespit edilmiştir. Liderler Covid-19 salgını ile mücadele konusunu vurgulamışlardır. Salgının ekonomiye olumsuz etkisi nedeniyle iktidar ekonomik destek paketlerini gündeme getirirken, muhalefet ekonomi politikalarını eleştirmiş̧tir. Bilim Kurulu, karantina, sağlık çalışanları ve sosyal mesafe konularında tüm liderler olumlu ve yapıcı tweetler paylaşmışlardır. Darbe iması konusunda Kılıçdaroğlu ve Erdoğan darbeye karşı olduklarını ifade etmişlerdir. Basın özgürlüğü, belediyelerin yardım kampanyaları, infaz düzenlemesi ve YKS'nin ertelenmesi konularında muhalefet iktidarı eleştirmiş̧tir. Milli Dayanışma Kampanyası'nı iktidar desteklerken, muhalefet kampanya için televizyondan IBAN paylaşılmasını eleştirmiştir. Tarım konusunda Bahçeli ve Akşener benzer fikirler paylaşmışlardır. Bahçeli gıda güvenliğinin sağlanması gerektiğini, Akşener ise tarımsal alanların korunması gerektiğini ifade etmiş̧tir. Bahçeli, Akşener'in liderlerin bir araya gelmesi ve sorunları birlikte çözme önerisini eleş̧irmiş̧tir. Yurtdışı yardımları konusunda Akşener, Erdoğan'ı eleş̧irmiştir. Akşener işsizlik konusuna, Erdoğan şehir hastaneleri konusuna değinmiş̧ir.

Anahtar Kelimeler: Siyaset, lider, söylem, Twitter, Covid-19.

\section{Giriş}

Çin'de 2019 yılının sonunda ortaya çıkan Covid-19 salgını hızla yayılarak tüm dünyayı etkisi altına almıştır. Virüs için bir tedavinin ve aşının olmaması hızla yayılmasına ve bu nedenle ciddi tedbirler alınmasına neden olmuştur. Salgın başta sağlık olmak üzere ekonomi ve eğitim gibi pek çok alanı etkilemiştir. İlerleyen süreçte karantina kararları alınmıştır. Türkiye, Covid-19 ile mücadelede erken önlem alan ülkelerden birisi olmuştur. Sokağa çıkma ve seyahat yasakları getirilmiştir. İyileşen hasta sayısının yeni vaka sayısını geçmesiyle normalleşme adımları atılmaya başlanmıştır. Normalleşme adımlarında 1 Haziran tarihi esas alınmıştır.

Salgınla mücadele ve alınabilecek önlemler konusunda siyasetçiler de söylemlerde bulunmuşlardır. Haber kaynağı olarak medyanın içeriklerinde yer alan siyasi liderler söylemleriyle sürece yön vermişlerdir. Liderler yeni medya alanında sosyal medya hesaplarını da, söylemlerini doğrudan halka ulaştırmak için kullanmışlardır. Liderler, mesajları kısa ve öz bir şekilde takipçilere iletmek için Twitter'da söylemlerini iletmişlerdir.

Bu çalışmada Covid-19 salgını sürecinde siyasi parti liderlerinin Twitter'da paylaştıkları söylemleri incelenmiştir. Bu amaçla Türkiye'de ilk vakanın görüldüğü 11 Mart ve normalleşme adımlarının atıldığ 1 Haziran tarihleri arasında liderlerin paylaştıkları tweetler çalışma kapsamına alınmıştır. Çalışmada Devlet Bahçeli, Kemal Kılıçdaroğlu, Meral Akşener ve Recep Tayyip Erdoğan'ın paylaştıkları tweetler incelenmiştir. Bu dört liderin seçilmesinin nedeni iktidar ve muhalefet olmaları, Cumhur ve Millet ittifaklarının tarafı olmalarıdır. Salgın sürecinde liderlerin gündemi, süreci nasıl yönettikleri tespit edilmeye çalışılmıştır. Çalışmada içerik analizi ve söylem çözümlemesi kullanılmıştır.

\section{Covid-19 Salgını}

Covid-19 salgını 2019 yılının sonunda Çin'de ortaya çıkarak tüm dünyayı etkisi altına alan ve sosyal hayatı dönüşüme uğratan bir süreci başlatmıştır. Salgın, sağlık, eğitim, ekonomi, siyaset ve çevre gibi alanları etkilemiş ve insanların davranış kalıpları ve alışkanlıklarında değişimi zorunlu hale getirmiştir. Virüsün ortaya çıkışı konusundaki çelişkili açıklamalar ve tartışmalar sürerken, virüs için bir tedavinin ve aşının olmaması hızla yayılmasına neden olmuştur. 
$\mathrm{Bu}$ süreçte ülkelerin sağlık sistemlerinin böyle bir salgına karşı ne kadar hazırlıklı olduğu karşılaştırmaları yapılmaya başlanmıştır. Hastane, sağlı personeli ve solunum cihazı sayıları gündeme gelmiştir. Ülkelerin aldıkları önlemler kimi zaman geç alındığı kimi zaman da yeterli olmadığı gerekçesiyle eleştirilmiştir. İlerleyen süreçte karantina kararları alınmış ve sosyal mesafeye dikkat edilmesi ve maske takılması özellikle vurgulanmıştır. Alınan karantina karaları ABD ve Fransa'da vatandaşlar tarafından gösteriler yapılarak protesto edilmiştir.

ABD'de karantinayı protesto ile başlayan gösteriler, Fransa'ya da sıçramış ve sokağa çıkma yasağı uygulanan ülkede polis ekipleri ve protestocular arasında arbede yaşanmıştır (“ABD’den sonra şimdi de Fransa: Paris’te sokaklar karıştı”, 2020).

Salgın sürecinde virüsün yayılma hızını düşürmek için okullarda eğitime ara verilmiştir. Bazı sektörlerde işler durma noktasına gelmiş, bu durum ekonomik sorunların ortaya çıkmasına neden olmuştur. İşsizlik, maaşların ödenememesi gündeme gelmiştir. Bu sorunlar ve alınabilecek önlemler siyasetçilerin söylemlerinde de ifade edilmiştir. Salgının yaratmış olduğu sorunlar ve çözüm önerileri üzerinde durulurken, bu süreçte insanın doğaya müdahalesi ve çevreye verilen zarar azalmıştır.

\subsection{Covid-19 Salgınının Ortaya Çıkışı ve Türkiye'deki Durum}

Haber ajanslarına 2019 yılının Aralık ayında, Çin'in Hubei eyaletinin Wuhan şehrinde bulunan bir deniz ürünleri pazarında, nedeni bilinmeyen çok sayıda pnömoni hastasının olduğu bildirilmiştir. Dünya Sağlık Örgütü (DSÖ), bu şikayetlerin sebebinin yeni tip bir koronavirüs olduğunu (2019-nCoV) 12 Ocak 2020 tarihinde açıklamış ve 11 Şubat 2020'de bu yeni virüs SARS-CoV-2 olarak adlandırılmıştır. Hastalardan edinilen numuneler sonucunda, 7 Ocak 2020'de SARS-CoV-2'nin tüm genom dizisi, Çinli bilim adamları tarafından kısa sürede haritalandırılmıştır. DSÖ başkanı Tedros Adhanom Ghebreyesus, 31 Aralık 2019 tarihinde Covid19 kodlamasının açılımını, 'korona' için 'CO', 'virüs' için 'VI', 'hastalık' için 'D' şeklinde tanımlamıştır. Salgın Çin'den sonra başta Asya ülkeleri olmak üzere kısa sürede birçok ülkeye yayılmış ve tüm dünyayı etkileyen uluslararası bir boyuta ulaşmıştır (Türkiye Bilimler Akademisi, 2020: 15).

Virüsün ortaya çıkması ve yeni bir virüs olduğunun tespit edilmesi sonrasında, bu kadar hızlı yayılarak bir salgın boyutuna ulaşacağı tahmin edilmemiştir. Daha önce ortaya çıkan Sars ve Mers virüsleri belirli bölgelerde etkili olduğundan, Covid-19 salgınının bu kadar yayılmayacağı da düşünülmüştür. Virüsün ilk ortaya çıktığı yer olan Çin diğer ülkelerin hedefi haline gelmiş ve ABD Başkanı Donald Trump virüsü 'Çin virüsü' olarak adlandırmıştır. DSÖ, virüsün salgın olduğunu geç ilan ettiği için eleştirilmiştir. Türkiye’ye virüs diğer ülkelere göre daha geç gelmiş ve ilk vaka 11 Mart'ta görülmüştür.

Bu virüsün, 7 Ocak 2020 tarihinde insana geçişi belirlenerek tanımlanan, SARS-CoV ve MERS-CoV gibi korona virüs ailesinden olup ciddi solunum yetmezliği oluşturan zarflı bir RNA virüsü olduğu açıklanmıştır. Bu virüsün de SARS-CoV ve MERS-CoV gibi bir zoonotik enfeksiyon yani hayvanlardan insanlara bulaştığı düşünülmektedir. Covid-19 ilk olarak deniz ürünleri pazarında bulunan insanlarda görülmüştür. Bilim insanları Covid-19'un yarasalardan bulaştığını düşünmüş olmasına rağmen Pazar yerinde yarasa satılmaması düşünüldüğünde, virüsün insanlara iletilmesinde bir tür ara hayvanın taşıyıcı olduğu görüşü ileri sürülmüştür. Günümüzde hastalık insandan insana hızla bulaşarak, hasta sayısı milyona ve ölüm sayısı onbinlere ulaşmıştır (Türkiye Bilimler Akademisi, 2020: 27).

Virüsün daha önce görülmemiş olduğu tespit edildikten sonra hayvandan insana bulaşan bir virüs mü olduğu, laboratuvar ortamında üretilen bir virüs mü olduğu konusundaki tartışmalar devam etmiştir. Fransa'da Nobel ödüllü virolog Profesör Luc Montagnier virüsün laboratuvarda üretilmiş olabileceğini öne sürmüştür. Virüsün ortaya çıkışıyla ilgili tartışmalar devam ederken, 
salgının yayılma hızı artmış, bu süreçte ülkelerin sağlık sistemleri sorgulanmış ve geç önlem aldıkları için eleştirilmişlerdir.

Türkiye, Covid-19 salgını ile mücadelede erken önlem alan ülkelerden birisi olmuştur. Önlemlerin erken alınması ve ilk vakanın diğer ülkelere göre daha geç görülmesi, salgınla mücadelede avantaj sağlamıştır. Türkiye'de ilk vakanın görüldüğü 11 Mart tarihi itibariyle Sağlık Bakanı Fahrettin Koca'nın açıklamaları ve yönlendirmeleri, Bilim Kurulu'nun oluşturulması ve Bilim Kurulu üyelerinin halkı bilgilendirmesi sürecin daha iyi yönetilmesine katkı sağlamıştır. Türkiye Bilimler Akademisi (2020: 30)'nin yaptığı sınıflandırmaya göre, Türkiye'de kaynağa, bulaşma yoluna ve sağlam kişiye yönelik olarak alınan önlemler şöyledir:

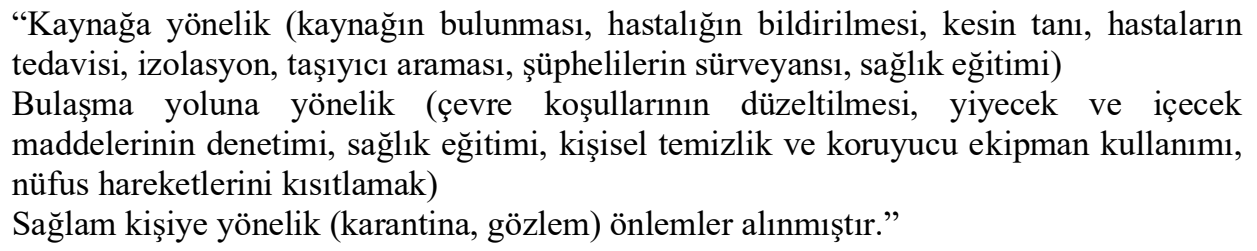

Hastalığın kontrolü farklı ülkelerde benzer uygulamalarla yapılmaktadır. Salgının başlamasıyla uçuşların durdurularak, seyahatlerin kısıtlanması, "Evde kal" çağrısının yapılması, yurt dışından gelenlerin karantinaya alınması, okulların kapatılması, kafe, lokanta, sinema, tiyatro, berber gibi toplu bulunulan yerlerin kapatılması, evden çalışma için esnek mesailerin uygulanması, şehirlerarası yolculukların yasaklanması gibi önlemler alınmıștır. Sağlık Bakanlığı tarafından oluşturulan Pandemi Bilim Kurulu, alınması gereken önlemler konusunda öneriler geliştirmiştir. İllerde İl Pandemi Kurulları oluşturulmuş, bu kurullarda halk sağlığı uzmanları görev almıştır (Çöl ve Güneş, 2020: 7).

20 yaş altı ve 65 yaş üstü vatandaşlara sokağa çıkma yasağı, 30 Büyükşehir ve Zonguldak iline giriş çıkış yasağı getirilmiştir. 10 Nisan'dan 6 Haziran'a kadar hafta sonları sokağa çıkma yasağ 1 getirilmiştir. Vaka sayısında düşüşün görülmesi üzerine 20 yaş altı ve 65 yaş üstü vatandaşların haftanın belirli günlerinde belirli saatlerde dışarı çıkmalarına izin verilmiştir. İyileşen hasta sayısının yeni vaka sayısını geçmesiyle normalleşme adımları atılmaya başlanmıştır. Normalleşme adımlarında 1 Haziran tarihi esas alınmıştır.

\subsection{Pandemi İlanının Gerekçeleri ve Salgının Hızla Yayılmasının Sebepleri}

Dünyada birden fazla ülkede veya kıtada, çok geniş bir alanda yayılan ve etkisini gösteren salgın hastalıklara pandemi adı verilmektedir. DSÖ’nün tanımlamasına göre, bir hastalığın pandemi olabilmesi için üç kriter aranmaktadır. Bunlar, yeni bir virüs veya mutasyona uğramış bir etken olması, insanlara kolayca geçebilmesi, insandan insana kolay ve sürekli bir şekilde bulaşması olarak sayılabilmektedir. Pandemi, belirgin kriterler gerçekleştiğinde DSÖ tarafindan ilan edilmektedir. Bu ilanın gerekçesi, tüm ülkeler için tehdit oluşturan yeni virüsün insandan insana kolay bir şekilde hızlıca yayılıyor olmasıdır (Türkiye Bilimler Akademisi, 2020: 19). DSÖ, 30 Ocak 2020 tarihinde, Covid-19'u uluslararası halk sağlığı sorunu kabul ederek salgın ilan etmiştir (Türkiye Bilimler Akademisi, 2020: 15).

Covid-19 salgını pek çok ülkede görülmesine ve geniş bir alanda etkisini göstermesine rağmen, pandemi olarak ilanı daha önce yapılmadığı için DSÖ eleştirilmiştir. Covid-19'un yeni bir virüs olduğunun tespit edilmesi, insanlara kolayca bulaşabilmesi ve bunun sürekli olması tüm ülkeler için tehdit oluşturmuştur. Salgın küreselleşmenin etkisiyle daha hızlı yayılabilme ortamı bulmuştur.

Ulaşımın kolaylaşması, hızlı küreselleşme, dünyanın herhangi bir yerindeki bir salgının çok hızlı bir şekilde yayılarak bütün ülkeler için ciddi tehdit oluşturmasına neden olmaktadır. Mevcut kronik rahatsızlıklar üzerine eklenen salgına bağlı hasta artışındaki yoğunluk gerek gelişmekte olan 
ülkeler gerekse de gelişmiş ülkelerin sağlık sistemi kapasitelerini olumsuz etkilemektedir (Türkiye Bilimler Akademisi, 2020: 20).

Ulaşım, ticaret ve teknoloji küreselleşmeye hız kazandırmakta ve ekonomik alanda hareketliliği arttırmaktadır. Böyle bir salgın döneminde ise bu hız ve hareketlilik hastalığın yayılma hızını olumsuz etkilemektedir. Ülkelerin sınırlarını kapatması ve uçuşları yasaklaması hastalığın yayılma hızını düşürme amacıyla alınan öncelikli tedbirler olmuştur.

Koronavirüse karşı mücadelede koronavirüsün çok bulaştırıcı olması ve hastalıktan korunmada en önemli strateji olan aşının henüz olmaması, diğer önlemlerin çok hızlı ve en etkili biçimde uygulanmasını gerektirmiştir. Şu ana kadar bu virüs için onaylanmış spesifik bir tedavi bulunmamaktadır. Koronavirüse karşı bir aşı da henüz geliştirilmemiştir, bununla ilgili Dünya'da 30'un üzerinde merkezde çalışmalar yapılmaktadır. Aşının ilk aşaması olan virüs izolasyonu yapılmışıı, ancak aşının hazır olması için zamana ihtiyaç duyulmaktadır. Bu nedenle hastalıktan korunma en önemli strateji olmaktadır (Çöl ve Güneş, 2020: 6).

Koronavirüsün tedavisi ve aşısı için çalışmalar sürdüğünden, en iyi korunma yolu virüsün bulaşabilme ihtimalini en aza indirecek önlemlerin alınması olmuş, bu süreçte maske takmak, sosyal mesafeyi korumak özellikle vurgulanmıştır. Virüsün taşıyıcısı olan ve hiçbir belirti göstermeyen insanlar da hastalığın daha hızlı yayılmasına neden olmuştur. Karantinaya, sosyal mesafe kurallarına uymayan ve maske takmayan insanlar da bilinçli olarak hastalığın yayılmasına neden olmuşlardır. Hastalığın yayılma hızı ve alınan önlemlerin etkisi açısından ülkeler bazında karşılaştırmalı analizler yapılmış ve hastalığın ülkelere göre yayılma hızı grafiklerle televizyon kanallarında gösterilmiştir. Elde edilen sayısal veriler, ülkelerin salgınla mücadele konusunda başarılı olup olmadıkları yönünde çıkarımlar yapılmasını sağlamıştır.

\section{Liderlik ve Lider Söyleminin Etkisi}

Liderlik, bir kişinin bir misyonu, görevi veya hedefi gerçekleştirmek için başkalarını etkilediği ve bir örgütlenmeyi daha birleştirici ve uyumlu hale getirecek şekilde yönlendirdiği karmaşı bir süreçtir. Kişi bu süreci inanç, değerler, etik, karakter, bilgi ve yetenekler gibi liderlik özelliklerini uygulayarak gerçekleştirmektedir (Jones, 2003: 10). Kişinin sahip olduğu liderlik özellikleri, bulunduğu grubun diğer üyelerinden öncelikli bir konuma gelmesine ve diğer üyeler adına söz söyleme ve eylemde bulunma hakkına sahip olmasına yol açmaktadır. Liderlik sadece grubun ya da örgütlenmenin sözcüsü olmakla da sinırlı değildir, liderin grup üyeleri üzerinde yönlendirici olması söz konusudur. Bu da liderin izinden giden takipçilerini önemli kılmaktadır.

Bir liderin başarılı olup olmadığını belirleyen lider değil, takipçileri olmaktadır. Başarılı olmak için takipçilerin ikna edilmesi gerekmektedir (Jones, 2003: 14). Etkili liderlikte, lider bir savunucudur ve onun liderlik tarzı koalisyondur. Etkisiz liderlikte ise liderlik tarzı manipülasyon olmaktadır (Jones, 2003: 21). Liderin grup üyelerini ikna etmesi için yönetiminin meşru görülmesi ve bu meşruluğa rıza gösterilmesi gerekmektedir. Meşru görülen ve rıza gösterilen bir liderin kitleleri harekete geçirme gücü liderin konumunu pekiştirmesine ve sürdürmesine katk1 sağlamaktadır. Bu da liderin başarısı olarak yansımaktadır. Bu rızanın sağlanması da liderin grubu temsil yeteneğine ve tabanın fikrinin lider tarafindan ne kadar savunulduğuna bağlı olmaktadır. Grup üyelerinin lider tarafından manipüle edilmesi, tabanda lidere duyulan güvenin azalmasına ve desteğin geri çekilmesine neden olmaktadır. $\mathrm{Bu}$ da liderin seçmenleriyle arasındaki ilişkiye odaklanmasını sağlamaktadır.

Stratejik liderler, kendileri ve seçmenleri arasındaki ilişkiye ve belirli bir karar ve eylemin bu ilişkiyi nasıl etkileyebileceğine odaklanmaktadır (Hermann vd., 2010: 6). Stratejik liderlik tarzına sahip liderlerin, eşit miktarda eylem ve retorik ile meşgul olmaları da ilginçtir (Hermann vd., 2010: 21). Liderin seçmenleriyle kurduğu ilişkinin otoriter bir tavra dayanması, otorite ortadan kalktığında liderlik vasfının da tanınmamasına neden olmaktadır. Bu nedenle liderin rızaya dayalı olarak kurulan ilişki ve iletişime önem vermesi ve seçmenin fikrini dikkate alması gerekmektedir.

Turkish Studies, 15(6) 
Liderin sadece yaptıkları değil, söylemleri de seçmende etki yaratmaktadır. Bu durum liderin hitabet gücünü, seçmene seslenişini, seçtiği sözcükleri önemli hale getirmektedir. Seçmen kendi savunduğu fikirleri seslendiren ve eyleme geçiren lidere ihtiyaç duymaktadır.

Siyasi liderliğin ortaya çıkışı konusunda demokratik seçimler gibi resmileştirilmiş seçim süreçlerinin dışında, siyasi liderliğin ortaya çıkmasının birincil nedeni, liderliğe olan talep ve bunun arzı olmaktadır (Schoeller, 2014: 7). Siyasi liderlik eğer bir arz ve talep varsa ortaya çıkmaktadır. Arz, liderden beklenen faydalara bağlı olurken, talep takipçilerin mevcut sermayelerine göre belirlenmektedir (Schoeller, 2014: 17). Siyaset bir toplumdaki üyelerin kendi fikirlerini savunacak ve eyleme geçirecek kişiyi seçmeleri ve yönetim erkini ona devretmeleri şeklinde işlemektedir. Seçimler sadece lidere olan talebin somutluk ve görsellik kazandığı bir aşama olmaktadır. Lider olacak kişinin sunumunda liderlik özelliklerini taşıması ve vaatlerini yerine getirme potansiyeli belirleyici olmaktadır. Lidere olan talepte ise her zaman siyasi bir ideoloji belirleyici olmamakta, bazen de kendi ekonomik konumlarını ve çıarlarını korumak isteyenler bir lideri destekleyebilmektedir. Liderin etkisi parti programının ve kadrosunun ikinci plana atılmasına neden olabilmektedir.

Bir siyasi parti, parti programı, parti kadrosu ve parti lideri olarak üç unsurdan oluşmaktadır. Bu üç unsurdan herhangi birisi siyasi partiyi iktidara götürmek için tek başına yeterli değildir. Bu unsurlardan en önemlisi de siyasi partinin lideri olmaktadır (Erzen, 2009: 197). Siyasal toplumsallaşma, siyasal inanç, değer ve davranışların birey tarafindan benimsenmesi ya da toplum tarafından bireye öğretilme süreci olarak tanımlanmaktadır (Kışlalı, 2010: 118). Siyasal toplumsallaşmada siyasal değer ve davranışların bireye öğretilmesinde liderin de etkisi bulunmaktadır. Lider, parti programı ve parti kadrosundan önce görünür olan ve kitleleri etkileyen bir unsur olmaktadır. Söylem seçkini olan liderlerin kitlenin davranış biçimleri üzerinde belirleyici olması söz konusudur.

Söylem seçkinleri, haber aktörü ya da kaynağ 1 olarak medya içeriklerinde yer alan siyasi, askeri ve ekonomik alandaki iktidar seçkinleri ve medyanın söylem üretiminde tematik yapının uygulanmasına katkı sağlayan sembolik seçkinlerin tümü olmaktadır (Rigel, 2000: 192). Siyasi liderler söylemleriyle haber kaynağı ve haber aktörü olarak medyanın içeriklerinde yer almakta, medya aracılığıyla söylemleri kitleye ulaştırılmaktadır. Medya bu süreçte söylemi tekrar inşa ederek üretmekte ve kimi zaman söylemi eksik ya da yanlış aktararak kitleyi manipüle edebilmektedir. Yeni medya alanında ise siyasetçilerin sosyal medya hesapları kendi medyaları olmakta ve doğrudan kitleyle iletişime ve etkileşime geçebilmektedirler. Bu bağlamda yeni medya siyasal iletişime farklı bir boyut kazandırmaktadır.

\section{Yeni Medyanın Siyasal İletişime Katkısı}

Yirminci yüzyıl boyunca, kitle iletişim araçları kurumsal statülerini güçlendirerek ve kamusal alanın örgütlenmesine rehberlik eden hakim bir söylem geliştirerek güç kazanmıştır (van Dijck ve Poell, 2013: 3). Kitle iletişim araçları egemen söylemin yeniden üretimini sağladıkları ölçüde kurumsal statülerini koruyabilmiştir. Hakim olan söylemleri aslında kendilerine dikte edilenden fazlası olmamıştır. Ürettikleri söylemi çoğunluğun kabul ettiği fikirler olarak yansıtma başarıları statülerinin belirleyicisi olmuştur.

Kitle iletişim mantı̆̆ında olduğu gibi sosyal medyanın mantığı da zamanla kamusal yaşamın tüm alanlarına yayılmıştır. Sosyal medyayı belirleyen kültürel ve ticari dinamikler, mevcut ticaret ve reklam alanındaki uygulamalara uyum sağlarken, aynı zamanda bu uygulamaları değiştirmiştir. Sosyal medya tarafsız bir platform olmaktan çok, sosyal etkileşimin koşullarını ve kurallarını etkileyen bir alan olmuştur (van Dijck ve Poell, 2013: 3). Yeni medya kamusal alana yayılarak var olan sisteme uyum sağlayan bir dönüşümü gerçekleştirmiştir. Yeni medya, kullanıcılarını özellikle ticaret ve reklam konusunda kitle iletişim araçlarından daha fazla etkisi altına almıştır. 
Atabek (2003: 70) kitle iletişim mantığının değişmesiyle ilgili olarak sahibi olmayan medya kavramını şöyle ifade etmiştir:

\begin{abstract}
"Tek tek cihazların, altyapıların sahipleri var tabii. Kablolar, linkler, routerler, hard diskler vs. bunlar tabii ki kimin ise onun, burada normal mülkiyet ilişkileri işliyor ama devasa bir medya olarak, ortak bir anlatı alanı olarak İnternet'in bir sahibi yok. Dolayisıyla bilinen anlamda sahibi olmayan bir medyadan bahsediyoruz."
\end{abstract}

Yeni medyada içerik aşamasında temel özellikleri etkileşim, çoklu ortam ve bağlanabilirlik olan bir dönüşüm yaşanmıştır. Tüketim aşamasında da etkileşim temelinde bir farklılaşma gözlenmektedir (Aydoğan ve Başaran, 2012: 222). Yeni medya alanında etkileşim ve çoklu ortam kitle iletişimindeki tek yönlülüğü ortadan kaldırmış, medya içeriğinin tüketiminde etkileşimin etkisiyle içeriğe yorum yapma, içeriği eleştirme ya da destekleme imkanını ortaya çıkarmıştır. $\mathrm{Bu}$ olanaklar siyasal iletişimde de bir dönüşümü beraberinde getirmiş, siyasetçiler sosyal medya hesapları üzerinden doğrudan kitleyle iletişime geçmeye başlamışlardır.

Sosyal medya siyasetçinin daha kısa sürede daha geniş bir kitleye hitap edebilmesini ve tepkilerini daha kolay ölçebilmesini sağlamıştır. Bu nedenle bu ortamlar güçlü bir politik araç haline gelmiştir. Siyasi oluşum içerisinde, fiziksel bir ortamda insanları miting alanına toplamak zordur. Sosyal medyada ise hazır kitleye ulaşmak mümkün olmaktadır. Haftanın 7 günü 24 saat boyunca politikacı seçmeni ile iletişim halinde olabilmektedir (Sütçü vd., 2013: 185-186). Siyasetçilerin sosyal medya hesapları aracılığıyla gerçekleştirdikleri siyasal iletişim zaman ve mekan kavramlarını anlamsızlaştırırken, iletişimi aracısız hale getirmiştir. Söylemin doğrudan iletimi, söylemin yeniden inşa edilerek tekrar üretilip kitleye sunulması aşamasını da ortadan kaldırmıştır. Yeni medya alanı siyasal iletişimde siyasetçilere eşit koşullarda kendilerini ifade etme olanağı sunarken, siyasi aktörlerin kişilik özellikleri, partileri, sosyal medyadaki konumları ve etki oranları farklılaşmayı ortaya çıkarmıştır.

Siyasi aktörler eşit koşullarda dijital alana girmemektedir. Sosyal medya başarılarında yaş, cinsiyet, eğitim, parti üyesi olma, ideoloji gibi kişisel özellikleri, görevi, oy oranı, medyanın ilgisi, mali kaynakları gibi yapısal özellikleri ve sosyal medyadaki etkinlikleri belirleyici olmaktadır (Keller ve Kleinen-von Königslöw, 2018: 1). Liderlerin sosyal medyada etkin olmaları, söylemleri ve takipçi sayıları dijital ortamdaki eşitsizliğin sürmesine neden olmaktadır. Bu nedenle liderler takipçilerinin yorumlarını dikkate almakta ve siyasetlerini buna göre yönlendirmektedirler.

Siyasi aktörün gönderisi, rakip içeriğe karşı görünürlüğünü artırmak ve sadece birkaç hayranı ve takipçisinden daha fazlasına ulaşmak için Facebook'ta beğeniler, yorumlar ve paylaşımlar, Twitter'da yanıtlar, beğeniler ve retweetler gibi tepkilere ihtiyaç duymaktadır. Bu nedenle iletişim ağının mantı̆̆ı, siyasi aktörlerin sosyal medya başarısının kullanıcıların tepkilerine büyük ölçüde bağl1 olduğunu iddia etmektedir (Keller ve Kleinen-von Königslöw, 2018: 2). Gönderiye verilen tepkiler liderin söylemi ya da eylemi için kabul ya da red süreci olarak işlemektedir. Kamuoyu yoklamaları gibi uzun bir süreç gerektiren işleme gerek duyulmadan, kamunun kanaati hakkındaki bilgi ilk elden ve daha çabuk sürede edinilmektedir. Liderler özellikle Twitter üzerinden mesajlarını vererek etki yaratmayı amaçlamaktadırlar.

\title{
4. Twitter'da Kurulmaya Çalışılan İktidar
}

Yeni medya günümüzde bir anlamda kișilerin kendi medyalarını yaratmalarına firsat vermiştir. Facebook, Twitter ve İnstagram en çok kullanılan sosyal paylaşım siteleridir. Facebook diğerlerine göre popülerliğini yitirmiştir. Twitter ise daha yazı odaklı olması nedeniyle bir kısım medya kullanıcısına hitap etmektedir. En çok tercih edilen platform fotoğraf ve video odaklı olduğu için İnstagram olmaktadır. Siyasal iletişimde ise siyasetçiler yazı odaklı olması, mesajları kısa ve öz bir şekilde takipçilere iletmesi nedeniyle Twitter'ı tercih etmektedir. Artık uzun yazılarla bir fikri temellendirmenin yerini kısa ve öz cümlelerle anlatmak almıştır. 

etmiştir:

Turgut (2013: 42) bu durumu uzun okuyamayan beyinler nitelendirmesiyle şöyle ifade

"Duygularla 'düşünmek', dış dünyadan gelen verileri anlama aşamasını atlayarak anlamlandırmak çağımızın koşullarının yarattığı yeni beyinlerin özelliğidir. Uzun okuyamayan bu beyinler aslında tüm dünyada geriye gidiyor"

Twitter'ın bu kadar rağbet görmesinin nedeni de 140 karaktere tüm düşünceyi sığdırması, mesajı kısaltması ve uzun okuyamayanlar için kısa söylemlerle istenilen mesajın daha fazla kitleye ulaşmasını sağlamasıdır. Kısa mesaj daha çok kişiye ulaştığından etkisi de hızlı olmaktadır. Twitter 2017 yılında karakter sayısını 280'e çıkarmıştır. Twitter'ın takipçi ve takip edilen özelliği sayesinde de bir bağl1lık oluşturulabilmektedir.

Twitter'ın ve benzer platformların herhangi bir aşırılık yanlısı faaliyetle doğrudan bir bağlantısı yoktur, ancak bağlanabilirlik ve aranabilirlik gibi gelişmiş özellikleri, kanaat oluşumuna, bağlılık yaratmaya ve topluluk oluşturmaya yardımcı olabilmektedir (Masroor vd., 2019: 3). Twitter'da yanıtlar, beğeniler ve retweetler ile benzer fikirlere sahip bireyler bir topluluk oluşturulabilmekte, gündemi etkileyebilmektedirler. Oluşturulan kanaatin karşısındaki farklı fikirlere sahip olanlar da bu karşıtlık üzerinden başka bir topluluğun oluşmasını sağlayabilmektedir. İdeolojik güç mücadelesi Twitter üzerinden devam edebilmektedir.

Siyasi tweetlerin söyleminde farklı düzeylerde işleyen iktidar ilişkileri ve iktidar yapıları vardır. Siyasi alanda iletişim için teknolojiye olan bağımlılığın artması söylem analizi açısından medyaya yönelik eleştirel araştırmalara daha fazla dikkat edilmesini gerektirmektedir. Siyasi alanda aktif olan kişilerin tweetleri ideolojilerin mücadelesini yansıttığı ve bu söylemler kamunun tüketimi için kolay erişilebilir olduklarından egemenlik ve güç fikri önemli olmaktadır (Masroor vd., 2019: 4). Farklı durumlarda ve bağlamlarda retweetlemenin anlamına bakılmaksızın, bulgular, insanların siyasi tartışmalardaki davranışlarının yalnızca kendi görüşleriyle uyumlu içeriği yaydıklarını göstermektedir (Guerrero-Solé, 2018: 2). Takipçiler Twitter'daki iktidar mücadelesini sürdürmek için savundukları fikirleri retwettlemektedirler. Bu medyanın yeniden söylem üretimine benzer bir süreç olarak işlemektedir. Bu iktidar mücadelesinin aktörleri olan liderlerin mesajlarının okunması, söylemlerinin takip edilmesi siyasete yön vermektedir.

\section{Liderlerin Twitter'daki Söylemlerinin Analizi}

Çalışmanın amacı Covid-19 salgını sürecinde siyasi parti liderlerinin Twitter'ı nasıl kullanarak süreci yönetmeye, gündemi belirlemeye ve kamuoyunu etkilemeye çalıştıklarını tespit etmektir. Virüsle mücadelede ortak paydada birleşmesi gereken liderlerin verdikleri mesajlarla, gündeme getirdikleri konularla sürece katkı mı sundukları, siyasi karşıtlıklar kurarak gündemi mi değiştirdikleri belirlenmeye çalışılmıştır.

Çalışmada Covid-19 salgını sürecinde siyasi parti liderlerinin Twitter'da paylaştıkları söylemleri incelenmiştir. Bu amaçla Türkiye'de ilk vakanın görüldüğü 11 Mart ve normalleşme adımlarının atıldığı ve kontrollü sosyal hayatın başladığı 1 Haziran tarihleri arasında paylaştıkları tweetler çalışma kapsamına alınmıştır. Dört siyasi parti liderinin paylaştıkları tweetler çalışmada incelenmiştir. Bu liderler Devlet Bahçeli, Kemal Kılıçdaroğlu, Meral Akşener ve Recep Tayyip Erdoğan'dır. Bu dört liderin seçilmesinin nedeni iktidar ve muhalefet konumunda olmaları ve 2019 yerel seçimlerinde Cumhur ve Millet ittifaklarının tarafı olmalarıdır. Devlet Bahçeli ve Recep Tayyip Erdoğan Cumhur ittifakını oluştururken, Kemal Kılıçdaroğlu ve Meral Akşener Millet ittifakını oluşturmuştur. Çalışmada içerik analizi ve Teun A. van Dijk'ın söylem çözümlemesi yöntemi kullanılmıştır.

İçerik analizinin amac1, kamusal alana yönelik olarak üretilen ve kurgulanan metinleri çözümlemek olmaktadır (Gökçe, 2006: 20). İçerik analizi yönteminde, nicel veya nitel göstergelerden hareket edilerek, mesajdan elde edilen psikolojik, sosyolojik, tarihsel, ekonomik 
bilgilerin ötesinde sonuçlara ulaşmak amaçlanmaktadır. İçerik analizinde kategorilendirme ile mesaj öğeleri tek tek ayırt edilmekte ve sonrasında belirli gruplara dağıtılmaktadır (Bilgin, 2006: 14). Van Dijk çalışmalarında tematik ve şematik yapılardan söz etmektedir. Şematik çözümlemede durumsallığa ve yorumlara yer vermektedir. Van Dijk mikro yapı çözümlemelerinde cümle yapıları üzerinde durmaktadır. Cümle yapılarında sözcük ve sözcük öbeklerinin seçimi, retorik sistematik ve hiyerarşik olarak yapılandırılmaktadır (İnceoğlu ve Çomak, 2009: 31-32). Metnin sözcük, cümle yapısı ve anlamlarını kapsayan mikro yapıda söylem stili ele alınmakta ve aynı konunun farklı bir biçimde nasıl ifade edildiği üzerinde durulmaktadır. Sözcük bağlamında sözcüklerin düz ve yan anlamları vurgulanmaktadır (Devran, 2010: 65). Yan anlam, anlamların öznelliğe ya da en azından öznelerarasılığa doğru kaydığı andır (Fiske, 2003: 116). Eğretilemede bilinmeyen bir şey bilinen bir şey açısından ifade edilmektedir. Düzdeğişmecede ise bir parçanın bütünü temsil etmesi sağlanmaktadır (Fiske, 2003: 124-127).

Çalışmada liderlerin tweetleri incelenmiş, öncelikle seçilecek temalarla ilgili tweetler ve genel konularla ilgili tweetler belirlenmiştir. Liderlerin çıkacakları programı önceden duyurdukları tweetler, özel gün kutlamaları, anma, vefat, başsağlığ tweetleri ve bu tweetlerle bağlantılı verilen mesajlar genel konularla ilgili tweetler olarak tanımlanmış ve çalışma kapsamına alınmamıştır. Tablo 1'de liderlerin belirlenen tarih aralığında yayınladıkları seçilecek temalarla ilgili tweet sayısı, genel konularla ilgili tweet sayısı ve toplam tweet sayısı gösterilmiştir. Seçilen temalarla ilgili tweetlerde de, liderlerin aynı gün içerisinde değindikleri aynı temayla bağlantılı tweet dizileri çalışmada sayısal olarak bir tema şeklinde Tablo 2'de gösterilmiştir.

Tablo 1: Liderlerin 11 Mart-1 Haziran Tarihleri Arasında Yayınladıklar1 Tweet Sayıs1

\begin{tabular}{|l|l|l|l|l|}
\hline & Devlet Bahçeli & $\begin{array}{l}\text { Kemal } \\
\text { Kiliçdaroğlu }\end{array}$ & Meral Akşener & $\begin{array}{l}\text { Recep Tayyip } \\
\text { Erdoğan }\end{array}$ \\
\hline $\begin{array}{l}\text { Seçilen temalarla } \\
\text { ilgili tweet sayıs1 }\end{array}$ & 99 & 17 & 59 & 61 \\
\hline $\begin{array}{l}\text { Genel konularla } \\
\text { ilgili tweet sayısı }\end{array}$ & 27 & 68 & 143 & 112 \\
\hline Toplam tweet sayıs1 & 126 & 85 & 202 & 173 \\
\hline
\end{tabular}

Çalışmada tweetler önce içerik analizi, sonra da van Dijk'ın eleştirel söylem çözümlemesine göre incelenmiştir. İçerik analizinde liderlerin mesajları incelenerek temalar belirlenmiş, hangi liderin mesajlarında hangi temaya ne kadar sıklıkla değindiği sayısal verilerle tablo halinde gösterilmiştir. Değinilen temaların ifade edildiği tweetler her liderin söylemi olarak belirlenen tema başlığının altında yazılmıştır. Seçilen lider tweetleri amaçsal örnekleme yöntemine göre belirlenmiştir. İçerik analizi tablosunda temalar ve lider isimleri alfabetik sıraya göre yazılmıştır. Teun A. van Dijk'in eleştirel söylem çözümlemesine göre tweetlerde üretilen yan anlamlar, kurulan karşıtlıklar, ötekileştirmeler, öznelleştirmeler, eğretilemeler ve düzdeğişmeceler tespit edilmeye çalışılmıştır. Temaların incelenmesinde liderlerin tweetleri de isimlerinin alfabetik sırasına göre verilmiştir. Liderlerin Covid-19 salgını sürecinde değindikleri temalar şu şekildedir: 
Tablo 2: Liderlerin Değindikleri Temaların İçerik Analizi

\begin{tabular}{|c|c|c|c|c|}
\hline & Devlet Bahçeli & $\begin{array}{l}\text { Kemal } \\
\text { Kılıçdaroğlu }\end{array}$ & Meral Akşener & $\begin{array}{l}\text { Recep Tayyip } \\
\text { Erdoğan }\end{array}$ \\
\hline 3600 ek gösterge & & & 1 & \\
\hline Adalet & & & 1 & 1 \\
\hline $\begin{array}{l}\text { Basının } \\
\text { bilgilendirme işlevi }\end{array}$ & 2 & & & \\
\hline Basın özgürlüğü & & 1 & 2 & \\
\hline $\begin{array}{l}\text { Belediyelerin } \\
\text { yardım } \\
\text { kampanyaları }\end{array}$ & & 1 & 5 & \\
\hline Bilim Kurulu & 2 & & & \\
\hline $\begin{array}{l}\text { Camide şarkı } \\
\text { çalınması }\end{array}$ & & 1 & & \\
\hline Covid-19 salgını & 6 & 3 & 1 & 20 \\
\hline $\begin{array}{l}\text { Cumhurbaşkanlığ1 } \\
\text { Hükümet Sistemi }\end{array}$ & 1 & & & \\
\hline Darbe iması & 1 & 1 & & 1 \\
\hline Eğitim & & & 1 & \\
\hline Ekonomi & 1 & 2 & 9 & 5 \\
\hline $\begin{array}{l}\text { Emeklilikte yaşa } \\
\text { takılanlar }\end{array}$ & & & 1 & \\
\hline Irkçılık & & & & 1 \\
\hline $\begin{array}{l}\text { İçişleri Bakanı } \\
\text { Süleyman } \\
\text { Soylu'nun istifası }\end{array}$ & 1 & & 1 & \\
\hline $\begin{array}{l}\text { İktidar ve } \\
\text { muhalefet çatışması }\end{array}$ & 2 & 1 & & 1 \\
\hline İnfaz düzenlemesi & & 1 & 2 & 1 \\
\hline İşsizlik & & & 4 & \\
\hline Karantina & & 1 & 2 & \\
\hline $\begin{array}{l}\text { Memleket Masası } \\
\text { fikri }\end{array}$ & 1 & & 3 & \\
\hline $\begin{array}{l}\text { Milli Dayanışma } \\
\text { Kampanyası }\end{array}$ & 1 & 1 & & 1 \\
\hline Olağanüstü hal ilanı & & & 2 & \\
\hline $\begin{array}{l}\text { Rusya'yla dış } \\
\text { ilişkiler }\end{array}$ & & & 1 & \\
\hline Sağlık çalışanları & 2 & & 1 & 2 \\
\hline Sosyal mesafe & 3 & & 1 & 1 \\
\hline Şehir hastaneleri & & & & 6 \\
\hline Tarım & 2 & & 3 & \\
\hline $\begin{array}{l}\text { YKS'nin } \\
\text { ertelenmesi }\end{array}$ & & 1 & 2 & 1 \\
\hline Yurtdışı yardımları & & & 1 & 1 \\
\hline
\end{tabular}


Liderlerin söylemleri belirlenen temalara göre çözümleme kategorilerine ayrılmış, her tema hakkında açıklama ve liderlerin yaklaşımı konusunda bilgi verilmiş ve açıklamalara kanıt oluşturan lider tweetleri tarihleriyle birlikte kronolojik sıraya göre yazılmıştır.

\section{1. 3600 Ek Gösterge}

Memurların, maaşlarını, emekli olduktan sonra alacakları maaşları ve emekli ikramiyelerini belirleyen ek göstergenin 3600'e yükseltilmesi ve kararın yasalaşması konusundaki beklentilere Akşener değinmiştir. İktidar tarafindan verilen ek göstergenin 3600'e çıkarılacağı sözünün tutulmamasını eleştiren Akşener, ek göstergenin 3600'e yükseltilmesi gerektiğini ifade etmiş ve sözün yerine getirilmemesi üzerinden iktidarı eleştirmiştir. Akşener "daha neyi bekliyorsunuz?" ifadesiyle sürecin gereksiz uzadığını vurgulamıştır.

\section{Meral Akşener'in Söylemi}

“\#Covid19 ile mücadelede üstün fedakarlık gösteren, sevdiklerinden ayrı düşme, hayatlarını riske atma pahasına salgınla savaş veren sağlık çalışanlarımıza ve polislerimize \#3600EkGösterge sözünüzü yerine getirmek için daha neyi bekliyorsunuz?” (6 Mayıs)

\section{2. Adalet}

Adalet konusuna Akşener ve Erdoğan söylemlerinde yer vermişlerdir. Akşener, adalet ve hukuk konusunda 1srarcı olacaklarına işaret ederken, Erdoğan Türkiye'nin bir adalet devleti olduğu vurgusunu yapmıştır. Akşener demokrasi, hukuk ve adalet konusunda 1srarcı olacaklarını belirterek, demokrasi, hukuk ve adaletin olmadığını işaret etmiştir. Ekonomi Bakanı için "damat" ifadesini kullanarak öznelleştirme yapmıştır. Ekonomideki büyüme vaatleri için "masal" sözcügünü kullanarak eğretileme yapmış ve vaatlerin gerçeklikten uzak olduğunu kastetmiştir.

\section{Meral Akşener'in Söylemi}

"Biz demokraside, hukukta, adalette 1srar etmeye devam edeceğiz. Çünkü onlar olmazsa kaliteli büyüme olmaz, damadın büyüme masalları olur." (13 Mart)

\section{Recep Tayyip Erdoğan'ın Söylemi}

"Türkiye, ilhamını medeniyetinden alan bir hamiyet, bir vefa, bir adalet, bir vakar devletidir." (14 Nisan)

\section{3. Basının Bilgilendirme İşlevi}

Salgın gibi halkın tümünü ilgilendiren kritik konularda basının doğru haberler vermesi daha da önem kazanmaktadır. Sürecin doğru yönetilmesi doğru bilgilendirmeyi gerektirmektedir. $\mathrm{Bu}$ dönemde basının bilgilendirme işlevinin önemine Bahçeli söylemlerinde yer vermiştir. Bahçeli, medyada yanıltıcı haberlere yer verilmemesi gerektiğini ifade etmiş ve Sağlık Bakanı'nın doğru bilgilendirmesine rağmen, bazı yayın organlarında yanıltıcı bilgilerle sürecin manipüle edilmesini eleştirmiştir. Bahçeli "kökünü kazıyıp" ifadesiyle eğretileme yaparak, salgının tamamen bitirilmesine işaret etmiştir.

\section{Devlet Bahçeli'nin Söylemleri}

"Sağlık Bakanımız her gün şeffaf ve samimi bir üslupla KOVID-19 virüsüyle ilgili gelişmeleri açıklayıp milletimizle en doğru bilgileri paylaşmaktadır. Bu gerçek ortadayken, televizyon ekranlarından maksadı aşan, farklı yerlere çekilen, kargaşa yaratan beyanatlara ne gerek vardır?" (27 Mart)

"Bilhassa yazılı ve görsel medya yanlış algılara, yalan haberlere, yanıltıcı görüşlere yer ve fırsat vermemelidir. En güçlü olduğumuz an, bir bakıma en zayıf olduğumuz andır. Salgının kökünü kazıyıp hasretini çektiğimiz günlere ulaşabilmek için zamana ihtiyacımız vardır." (7 May1s) 


\section{4. Basın Özgürlüğü}

RTÜK tarafından FOX televizyon kanalına, Fatih Portakal'ın sunduğu FOX Ana Haber bülteninde 30 Mart, 31 Mart ve 1 Nisan tarihlerinde yayın ihlali yapıldığ gerekçesiyle idari yaptırım ve üç kez yayın durdurma cezası verilmiştir. Kılıçdaroğlu ve Akşener, bu duruma tweetlerinde değinmişlerdir. Kılıçdaroğlu gazetecilerin susturulamayacağını ifade etmiş ve basının özgür olmaması üzerinden iktidarı eleştirmiştir. Cezayı kınayan Akşener, demokrasi ve adaletin geleceğini dile getirerek, demokrasi ve adaletin olmadığını ima etmiştir. İktidarı basına yasak koymakla eleştiren Akşener, "yanan mutfak" söylemiyle eğretileme yaparak, halkın ekonomik durumunun kötüleşmesini ifade etmiştir.

\section{Kemal Kılıçdaroğlu'nun Söylemi}

"Halkın haber alma hürriyetini savunan gazetecileri asla susturamayacaksınız." (16 Nisan)

\section{Meral Akşener'in Söylemleri}

"Ülkemizin birkaç özgür medya kurumundan biri olan FOX TV’ye verilen ağır cezayı şiddetle ve esefle kınıyorum. Bugünler elbette geçecek, ülkemize demokrasi, adalet ve huzur gelecek. Bunu hep birlikte başaracağız!" (16 Nisan)

"Yasaklar diye diye geldin yasaklaya yasaklaya gidiyorsun Sayın Erdoğan... Beni ekranına çıartan Habertürk'e ceza verince bu millet yanan mutfağı, kararan umutları görmeyecek mi, sandıkta son sözü söylemeyecek mi sanıyorsun?" (7 Mayıs)

\section{5. Belediyelerin Yardım Kampanyaları}

Covid-19 salgını sürecinde bazı sektörlerde işlerin durma noktasına gelmesi, ekonomik sıkıntıların yaşanmasına neden olmuştur. $\mathrm{Bu}$ dönemde belediyeler yardım kampanyaları düzenlemişlerdir. İçişleri Bakanlığı tarafindan valiliklere gönderilen genelgeyle yardım kampanyalarının valilik iznine bağlı olduğu bildirilmiş, bu durum iktidar ve muhalefeti karşı karşıya getirmiştir. Belediyelerin yardım kampanyalarına Kılıçdaroğlu ve Akşener tweetlerinde değinmiştir. Kılıçdaroğlu ihtiyaçların belediyeler tarafından karşılanacağını ifade etmiş, Akşener belediye başkanlarının hizmetlerine engel olunduğunu belirtmiştir. Belediyelerin yardım kampanyalarının valilik iznine bağlanmasının nedenini, 2019 yerel seçimlerinde İstanbul ve Ankara belediyelerinin Millet ittifakının belediye başkan adayları tarafından kazanılması olarak gösteren Akşener, iktidarı milli iradeyi yok saymakla, milli iradeye müdahale etmekle ve güçlünün hukukunu korumakla eleştirmiştir.

\section{Kemal Kılıçdaroğlu'nun Söylemi}

"Sevgili yurttaşlarım! Sokağa çıkma yasağında ihtiyaçlarınız hem belediyelerimiz hem de diğer yetkililer tarafından karşılanacaktır. Lütfen panik oluşmasına izin vermeyin, sükunetinizi ve sağlığınızı koruyun, evde kalın size ulaşılacaktır. Sağlığınız her şeyden önemli!” (11 Nisan)

\section{Meral Akşener'in Söylemleri}

"Millet İttifakının belediye başkanları Sayın @ekrem_imamoglu ve Sayın @ mansuryavas06, hükümetin rakipleri değil. El ele verip endişeli vatandaşlarımızın dertlerine derman olmak varken, beka sorunu söylemiyle belediyelerimizi düşman göstermek, bir zeka sorunudur." (22 Nisan)

"6 milyon + 1" (25 Nisan)

"Şeytan kovalamaktan, namaz kılmaya vakit bulamıyor, @ekrem_imamoglu. Ne İstanbul Büyükşehir Belediyesiymiş, ne travmaymış. Bir sene geçti. Hala atlatamıyorlar." (29 Nisan) 
"Geçmişte milli iradeyi yok sayanların, haklının hukuku yerine güçlünün hukukunu koruyanların karşılarında oldum; bugün de aynı yerdeyim. Dün kendilerine yapılanları, bugün @ekrem_imamoglu ve @mansuryavas06'a yapanların karşısındayım.” (30 Nisan)

"Siyasi tarihimiz bize büyük milletimizin kendi iradesine müdahale edilmesini asla kabul etmeyeceğini gösteren örneklerle dolu. Yerel seçimlerden ders almayıp belediye başkanlarının hizmetlerine engel olan Sayın Erdoğan, milletin cevabını sandıkta alacak.” (17 Mayıs)

\section{6. Bilim Kurulu}

Covid-19 salgınının ortaya çıkmasının ardından Sağlık Bakanlığı tarafından 10 Ocak tarihinde alanlarında uzman bilim insanlarının yer aldığı Bilim Kurulu oluşturulmuştur. Bilim Kurulu'nun tavsiyeleri ve medya aracılığıyla yaptıkları bilgilendirmeler sürece katkı sağlamıştır. Bilim Kurulu'nun sürece olumlu katkısına Bahçeli tweetlerinde yer vermiştir. Bahçeli Bilim Kurulu'nun tavsiyelerinin bağlayıcılığını vurgulamıştır.

\section{Devlet Bahçeli'nin Söylemleri}

"Bilim Kurulumuzun 26 muhterem üyesi bulunmaktadır. Hepsi de birbirinden değerli bu bilim insanlarının fedakarca çalışmaları ümitlerimizi diri tutmaktadır. Ancak bu bilim insanlarının her birisi farklı farklı televizyon kanallarına çıkıp sürekli aynı şeyleri tekrarlamaktadır." (27 Mart)

“Bilim Kurulu'nun tavsiyeleri, Sağlı Bakanlığı'nın tembih ve tedbirleri herkes için bağlayıcıdır. Hiç kimse sorumsuz ve duyarsız hareket etmemelidir. Bana bir şey olmaz diyenler kendilerini düşünmüyorlarsa temas ettiği insanları düşünmek, dikkate almak mecburiyetindedir." (7 May1s)

\section{7. Camide Şarkı Çalınması}

İzmir'de 20 Mayıs tarihinde bazı camilerin hoparlöründen şarkı çalınması tepkilere neden olmuştur. Bu provokasyon iktidar ve muhalefeti karşı karşıya getirmiştir. Kılıçdaroğlu söyleminde camilerde ezan ve İstiklal Marşı dışında bir sesin yükselmesini kabul etmediklerini belirtmiştir.

\section{Kemal Kılıçdaroğlu'nun Söylemi}

"İbadet yerleri kutsalımızdır! Camilerimizden ezan ve İstiklal Marşı dışında başka herhangi bir sesin yükselmesini asla kabul etmiyoruz. İzmir'de yaşananların faillerinin bir an önce bulunmasını istiyoruz." (22 Mayıs)

\section{8. Covid-19 Salgını}

Covid-19 salgınına tüm liderler söylemlerinde yer vermiş ve salgınla mücadele konusunda olumlu ve yapıcı tweetler paylaşmışlardır. Bahçeli, Türkiye'nin yoğun bir mücadele içinde olduğunu ve bu süreçte devlet-millet dayanışmasının en üst seviyede olduğunu aktarmıştır. Bahçeli söylemlerinde eğretilemeler kullanarak, "aynı cephede savaşıyor" ifadesiyle ortak bir şekilde mücadele edildiğini, "at koşturuyor" ifadesiyle virüsün tüm dünyada çok hızlı bir şekilde yayıldığını, "diken üstünde, bıçak sırtında" ifadeleriyle virüs nedeniyle duyulan tedirginliği, "yürekten kopan çığlık" ifadesiyle virüs nedeniyle yaşanan zorlukları, "yüreğin hazin telleri" ifadesiyle insanların başkalarının yaşadıkları zorluklara duyarlı olduklarını, "köprüler kurulmuş" ifadesiyle ülkeler arasındaki dayanışmayı, "aynı mevzide" ifadesiyle ortak mücadeleyi, "sancılı ortam" ifadesiyle virüsün hızlı yayılması nedeniyle yaşanan sıkıntılı süreci belirtmiştir. Kılıçdaroğlu, salgının aşılacağını ve vatandaşların mağdur olmasına izin verilmeyeceğini ifade etmiş, salgına karş1 13 maddelik öneri sunmuştur. Akşener, virüsün doğaya verilen zarara ayna tuttuğunu belirtmiş ve sürecin insan olmayı yeniden hatırlattığını dile getirmiştir. Erdoğan, siyasi ve sosyal düzende köklü değişiklikler yaşanması muhtemel yeni bir döneme girildiğini, koronavirüse karşı amansız bir mücadele verildiğini, kurallara uyulması gerektiğini ve birlik ve beraberliğin önemli olduğunu ifade etmiştir. Erdoğan salgınla mücadele tweetlerinde salgın 
sonrasında, küresel sistemde Türkiye'nin hedeflerine ulaşması konusundaki kararlılıklarını da aktarmıştır. Erdoğan "canla başla" ifadesiyle eğretileme yaparak, devletin tüm gücüyle salgınla mücadele ettiğini belirtmiştir.

\section{Devlet Bahçeli'nin Söylemleri}

"İnsanlık bir virüse karşı aynı cephede savaşıyor. Tehlike ne ülke tanıyor, ne millet takıyor! Tehdit her kıtada at koşturuyor, her coğrafyada hüküm sürüyor. KOVID-19 salgını adım adım dünyayı dolaşıyor. Bütün ülkeler ortak bir amaçta birleşip hastalığa karşı direniyor." (21 Mart)

"Beşeriyet olağanüstü bir sürecin bütün yönlerini ağır bir şekilde yaşamaktadır. Ölümcül bir virüs insanlığa adeta savaş açmış durumdadır. Ülkeler, milletler, medeniyetler diken üstünde, bıçak sırtında, tahammül sınırındadır. KOVID-19 musibetiyle mücadele de üst noktadadır." (27 Mart)

"KOVID-19 salgını dünyaya bulaşmakla kalmamış, insanlık değerlerinin yekpare hatırlanıp kuvveden fiile çıkışını da tetiklemiştir. Bir yürekten kopan çı̆̆lık, bir başka yüreğin hazin tellerini titretmiştir. Coğrafyalar arasında köprüler kurulmuş, ülkeler aynı mevzide buluşmuştur." (7 Nisan)

"Türkiye her alanda çok yoğun ve sıcak bir mücadelenin içindedir. Bilhassa yeni tip Koronavirüs (KOVID-19) salgınını engellemek amacıyla devlet-millet dayanışması en üst seviyededir. Aynı zamanda bugünkü sancılı ortamda seferberlik ruhuyla hareket edilmektedir." (13 Nisan)

"KOVID-19 salgınına karşı bütün imkan ve irademizle direniyoruz. İnsan ve toplum sağlığının muhafazası ve müdafaası amacıyla her türlü tedbir zamanında, eşgüdüm ve eşzamanlı şekilde devreye sokuluyor. Türkiye büyük bir musibetle mücadele ediyor." (7 Mayıs)

"İçinden geçtiğimiz ve bütün ağırlı̆̆ını hissettiğimiz KOVID-19 salgını hayata bakışımızı, sosyal ve toplumsal ilişkilerimizi, siyasi ve ekonomik iletişimimizi müessir derecede tayin, hatta tevzi ve teçhiz etmektedir. "Yeni Normal"in tesiri "Eski Normal"den farklı olacaktır." (14 Mayıs)

\section{Kemal Kılıçdaroğlu'nun Söylemleri}

"Bu salgını aşacağız, milletimizin yanındayız!" (17 Mart)

"Koronavirüs (COVID-19) salgınına karş1 13 maddelik öneri” (24 Mart)

"Bu süreçte hiçbir vatandaşımızın mağdur olmasına izin vermeyeceğiz!" (1 Nisan)

\section{Meral Akşener'in Söylemi}

"Koronavirüs salgını hem doğaya verdiğimiz zarara ayna tuttu, hem de bize ölümün ne kadar yakın, insani hırsların ne kadar boş olduğunu gösterdi. Kısacası, bize insan olmayı yeniden hatırlattı. İnşallah öğrendiklerimizden, gördüklerimizden çıkardığımız bu dersler kalıcı olur.” (25 Nisan)

\section{Recep Tayyip Erdoğan'ın Söylemleri}

"Türkiye inşallah bu sıkıntıyı herhangi bir kayıp vermeden atlatacaktır. Hiçbir virüs bizim tedbirlerimizden güçlü değildir.” (11 Mart)

"Bölgesel ve küresel düzeyde içinden geçtiğimiz bu zor süreçte, diplomasiyi ve iş birliği mekanizmalarını daha aktif bir biçimde işletecek, sorunlarımızı bir an önce çözüme kavuşturmak için çalışmalarımızı kararlılıkla sürdüreceğiz." (17 Mart)

"Küresel ekonomik, siyasi ve sosyal düzende köklü değişiklikler yaşanması muhtemel yeni bir döneme giriyoruz. Artık hiçbir şeyin eskisi gibi gitmeyeceği, gidemeyeceği açıkça ortadadır." (18 Mart) 
"Koronavirüs'e karşı amansız bir mücadele yürütüyoruz. Bu virüs en çok yaşlıları ve kronik hastalığı bulunanları etkiliyor." (20 Mart)

“Aziz vatandaşlarım, Müsterih olunuz. Devletimiz tüm kurumlarıyla görevinin başında, zaman mefhumu gözetmeksizin Milletinin hizmetinde. Bu zorlu süreci inşallah hep birlikte atlatacağız. Yeter ki kurallara, yönlendirmelere uyalım ve mutlaka evlerimizde kalmaya devam edelim." (22 Mart)

"Milletimizin hizmetinde mesaimiz devam ediyor. Tüm kurum ve kuruluşlarımızın çalışmalarını yakından takip ediyor, adımlarımızı eşgüdüm içerisinde atmayı sürdürüyoruz." (24 Mart)

"Hiçbir düşman Milletimizin birliğinden, beraberliğinden, gücünden, dirayetinden daha üstün değildir. İnşallah bu Koronavirüs tehdidini de birlik, beraberlik içinde yeneceğiz." (25 Mart)

“Türkiye, Avrupa ve Amerika'ya kıyasla bu hastalığın yayılmasının üstesinden gelmeye en yakın ülkelerden biridir." (30 Mart)

"Türkiye'nin sağlı altyapısı; personel, ilaç, malzeme ve yoğun bakım imkanları bakımından pek çok ülkeye göre oldukça iyi durumdadır. Sağlı altyapımızın gücüyle, Koronavirüs'e karşı mücadele gibi zor bir süreci de inşallah örnek bir sınav vererek atlatacağız." (2 Nisan)

“Ülkemizde hayatı normale döndürmek 83 milyon olarak bizim elimizde. KOVID-19'a karşı mücadele çerçevesinde attığımız adımlara yenilerini ekliyoruz. Birliğimize, beraberliğimize sahip çıkıp tehdit tam olarak ortadan kalkıncaya kadar kurallara harfiyen uymalıyız." (3 Nisan)

"Vatandaşlarımızın her birinin temel hizmetlere ve ihtiyaç malzemelerine ulaşma konusunda sıkıntıya düşmemesi için ne gerekiyorsa yapıyoruz. Karamsarlığa ve rehavete kapılmadan her türlü ihtimali göz önünde bulundurarak tedbirlerimizi adım adım alıyor, hayata geçiriyoruz." (6 Nisan)

“Allah'ın izniyle Koronavirüs'le savaşı elbette kazanacağız. Ardından da yeni bir dünya gerçeğiyle karşı karşıya kalacağız. Bu nedenle, bir taraftan mücadelemizi sürdürürken diğer taraftan da salgın sonrası dönem için hazırlık yapmalıyız." (10 Nisan)

"Unutmayınız, bu salgının üstesinden ancak 83 milyon hep birlikte hareket edersek gelebiliriz. Birliğimize, beraberliğimize, kardeşliğimize sarıldığımız ölçüde geleceğimize güvenle bakabiliriz." (20 Nisan)

“Türkiye bu sıkıntılı dönemi, istikbaline daha güvenle ve umutla baktığı bir motivasyonla geride bırakıyor. Gücünü inancımızdan alan sabrımızla, milli birliğimizle, gelişmiş yerli üretim altyapımızla, örnek dayanışmamızla gösterdiğimiz fedakarlığın neticelerini almaya başlıyoruz.” (27 Nisan)

"Bizler bu süreçlerde bilimin, ortak aklın ve vicdanın yolunda karar alırken tüm kesimlerin faydasını gözetiyor, bu aziz milletin her bir ferdinin bu süreçten sağ salim çıkması için canla başla, 7/24 çalışıyoruz." (5 Mayıs)

"Küresel Koronavirüs salgınına karşı 83 milyon hep birlikte verdiğimiz mücadeleyi başarıyla devam ettiriyoruz. Sağlıkla ilgili hassasiyetlerimizden asla taviz vermeden milletimizi ve ülkemizi geliştirmeye, kalkındırmaya, büyütmeye, güçlendirmeye devam etmekte kararlıyız." (11 May1s)

“Allah'ın yardımı ve milletimizin desteğiyle Türkiye’yi dünyanın en gelişmiş 10 ülkesinden biri haline getirme hedefimize ulaşmakta kararlıyız. Koronavirüs salgını sonrası yeniden oluşacak küresel yönetim sisteminde Türkiye, inşallah hak ettiği yeri alacaktır." (12 May1s) 
"Türkiye olarak sadece kendi sınırlarımız içinde bu salgını yenmemiz yetmiyor. Yakın çevremiz başta olmak üzere dünyanın tamamında salgın etkisiz hale gelene kadar teyakkuz halinde olmayı sürdüreceğiz." (22 Mayıs)

"Halkımız, yaptığı hiçbir fedakarlığın boşa gitmediğinden emin olmalıdır. Allah'ın izni, milletimizin gayreti, devletimizin katkısıyla, son 2,5 aydaki kayıplanımızın hepsini de çok kısa bir sürede ziyadesiyle geri alacağımızdan en küçük bir şüphemiz yoktur." (28 Mayıs)

"Türkiye hem mevcut imkanlarını en iyi şekilde kullanarak hem de yeni imkanlar üreterek sağlık alanında farklı bir konuma gelmiştir. Ülkemiz her alanda hedeflerine doğru kararlılıkla ilerlemektedir." (29 Mayıs)

\section{9. Cumhurbaşkanlığı Hükümet Sistemi}

Cumhurbaşkanlığı Hükümet Sistemi'ni destekleyen Bahçeli söyleminde, sistemin işleyişi açısından kamuoyunun isabetli bilgilendirildiğini belirtmiştir. Cumhur ittifakı ortağ 1 olan Bahçeli, Cumhurbaşkanlığı Hükümet Sistemi'ni başarılı bulduğunu dile getirerek iktidarı desteklemiştir.

\section{Devlet Bahçeli'nin Söylemi}

"Cumhurbaşkanlığ1 Hükümet Sistemi devreye gireli 628 gün olmuştur. Bu süre zarfinda AK Parti’nin sözcülüğ̈̈ görevini Sayın Ömer Çelik, Cumhurbaşkanlığı Sözcülüğünü de Sayın İbrahim Kalın gayet başarılı bir şekilde yapmışlar ve kamuoyunu isabetle bilgilendirmişlerdir." (27 Mart)

\section{10. Darbe İması}

CHP Grup Başkanvekili Özgür Özel’in "Saray rejiminin, Saray düzeninin sonu geliyor" söylemine ve CHP İstanbul İl Başkanı Canan Kaftancıŏlu'nun "bir sistem değişikliğine gidişatı görüyorum." söylemine, AKP Sözcüsü Ömer Çelik "askeri ve yargı vesayetini davet ederek demokrasiyi felç etme örgütü" şeklinde karşıllk vermiştir ("Türkiye'de darbe tartışması nasıl başladı, kim ne söyledi?", 2020). Bu açıklamalar hükümet ve muhalefet arasında darbe iması tartışmasına neden olmuştur. Darbe konusuna söyleminde değinen Bahçeli, CHP'yi demokrasi ve özgürlük konusunda samimiyetsiz olarak nitelendirmiş ve darbeyi çağrıştıran söylemlerde bulunduğunu ima ederek muhalefeti eleștirmiștir. "CHP yönetimi" ifadesiyle karșıtlık kurarak muhalefet olmasına vurgu yapmıştır. Bahçeli söyleminde eğretilemeler kullanarak, "kafese koymak isteyenler" ifadesiyle ülkeye düşman olanları, bağımsızlığını elinden almak isteyenleri, "göz yumar" ifadesiyle olumsuz bir duruma tepki göstermemeyi, "demokrasi boyası sürerler" ifadesiyle muhalefetin demokrat olmadığını, "özgürlük hunisi geçirirler" ifadesiyle özgürlük yanlısı göründüklerini ama öyle olmadıklarını belirtmiştir. Kılıçdaroğlu darbeyi güçlendirenlerin darbeye karşı olduklarını söylemelerinin aldatmaca olduğunu belirterek iktidarı eleştirmiştir. Darbeyi güçlendirenlerin darbeye karşı olduklarını söylemelerinin çelişkili olduğunu ifade etmiş ve halkı kandırdıklarını ima etmiştir. Erdoğan demokrasiyi darbeci zihniyete karşı koruduklarını ifade etmiş, "darbeci zihniyet" ifadesiyle düzdeğişmece kullanarak CHP'yi kastetmiş ve siyasi karşıtlık kurmuştur. "Darbeci zihniyet" ifadesi yan anlam düzeyinde sorunların askeri müdahale ile çözüleceğini savunanları çağrıştırmaktadır. Erdoğan söyleminde eğretilemeler kullanarak, "son kale" ifadesiyle demokrasinin korunması için çaba sarf edildiğini, "göz bebeği" ifadesiyle demokrasiye önem verildiğini, "canla başla" ifadesiyle demokrasinin varlığı için mücadele edildiğini belirtmiştir. Üç lider de darbeye karşı olduklarını siyasi karşıtlık kurarak vurgulamışlar ve biz-öteki karşıtlığını yaratmışlardır. Biz darbeye karşı olmak, öteki ise darbeyi desteklemek olarak kodlanmıştır.

\section{Devlet Bahçeli’nin Söylemi}

“Bu CHP yönetimi ki, Türkiye’yi tuzağa çekip kafese koymak isteyenlere göz yumar. Samimiyetsiz olduklarından yüzlerine demokrasi boyası sürerler, kafalarına özgürlük hunisi 
geçirirler, siyasetlerine zincir vurdururlar, sonra da darbeyi çağrıştıran şifreli mesaj verirler." (9 May1s)

\section{Kemal Kılıçdaroğlu'nun Söylemi}

"Şunu bütün vatandaşlarımın bilmesini isterim. Darbe hukukunu tahkim edenlerin, güçlendirenlerin "biz darbelere karşıyız" demeleri tam bir aldatmacadır...” (27 Mayıs)

\section{Recep Tayyip Erdoğan'ın Söylemi}

"Medeniyetimizin son kalesini, mazlumların tek umudunu, evimizi, yurdumuzu, göz bebeğimizi, yani Türkiye Cumhuriyeti'ni ve demokrasimizi bu darbeci zihniyete karşı korumak ve hep bir adım ileriye taşımak için canla başla çalışmaya devam edeceğiz." (27 Mayıs)

\section{11. Eğitim}

İlk vakanın Türkiye'de 11 Mart tarihinde görülmesiyle, 12 Mart tarihinde okulların 2 hafta süreyle tatil edilmesi kararı alınmış ve 13 Mart itibariyle okullar tatil edilmiştir. Uzaktan eğitim verilmeye başlanmıştır. Uzaktan eğitim için hazırlanan videoda Adnan Menderes'in idam görüntülerinin animasyonunun gösterilmesi tepkilere neden olmuştur. Bu konuya değinen Akşener, Milli Eğitim Bakanı Ziya Selçuk'a 'yapanlardan hesap soracak mısınız' diye sorarak iktidarı eleştirmiştir. Akşener "gözden kaçıramaz" ifadesiyle eğretileme yaparak, dikkatli olunmamasına değinmiştir.

\section{Meral Akşener'in Söylemi}

"Milli Eğitim Bakanı olmak çocuklarımızın geleceğinden sorumlu olmaktır. Çocuklarımız kendisine emanetken, Milli Eğitim Bakanı "gözden kaçıramaz", "tüh, pardon" diyemez, yapılanın hesabını sorar. Çocuklarımıza bunu yapanlardan hesap soracak mısınız @ ziyaselcuk?” (23 Mart)

\section{12. Ekonomi}

Salgın sürecinde kimi sektörlerde çalışma hayatına ara verilmesi ekonomik sorunları ortaya çıkarmıştır. Bu süreçte ekonomi, salgından sonra üzerinde en çok konuşulan konu olmuştur. Muhalefet ekonomi politikaları üzerinden iktidarı eleştirirken, iktidar Ekonomik İstikrar Kalkanı Paketi ile ekonomi politikalarını savunmuştur. Bahçeli, Türkiye ekonomisinin operasyonlara maruz kaldığına değinmiş, "ayak oyunları" ifadesiyle eğretileme yaparak ekonomik krizlerin hileler sonucunda yaratıldığını belirtmiştir. Kılıçdaroğlu, Antalya'nın Serik Belediyesi’nde 500 bin liralık rüşvet alındığ iddiasını gündeme getirmiş ve iktidarı bu iddianın üzerine gitmemekle eleştirmiştir. Akşener, ekonomi politikalarını en fazla eleştiren lider olmuştur. Akşener, tweetlerinde vatandaşın zor durumda olduğuna yer verirken, salgın paketinde konut kredisi olmasını ve televizyondan yardım kampanyası için halka IBAN gönderilmesini eleştirmiştir. İktidarı ekonomik göstergeler üzerinden eleştiren Akşener, zorunlu karantinanın iktidarın ekonomi politikalarındaki başarısızlık nedeniyle uygulanamadığını belirtmiştir. Erdoğan, ekonomik destek paketleriyle vatandaşların krizin etkilerinden korunacağını ve istihdamı korumak, gelirini kaybeden vatandaşlara sahip çıkmak ve üretimi desteklemek için her önlemi aldıklarını savunmuştur. Erdoğan söyleminde eğretilemeler yaparak "sancılı" ifadesiyle salgın döneminde karşılaşılan sıkıntıları, "ayakta tutmak" ifadesiyle salgın nedeniyle ekonomik zorluk yaşayan esnafin daha az etkilenmesi için gösterilen çabayı belirtmiştir.

\section{Devlet Bahçeli'nin Söylemi}

"Türkiye ekonomisi yakın zamanda dört şiddetli operasyona maruz kaldı. Ağustos 2018, Mart 2019, Ekim 2019 ve 6 Mayıs 2020. Hafiza kayıtlarımızda mahfuzdur: 2000 ve 2001 krizlerinde hangi ayak oyunları, hangi karanlık senaryolar devreye alındıysa şimdilerde benzerleri uygulanmaktadır." (9 Mayıs) 


\section{Kemal Kılıçdaroğlu'nun Söylemleri}

"500 bin liralık rüşveti kim aldı? \#500BinRüşvetiKimYedi” (8 Mayıs)

"Erdoğan'a soruyorum; 500 bin liralık rüşveti kim aldı?” (20 Mayıs)

\section{Meral Akşener'in Söylemleri}

"Vatandaşımız çok zor durumda, geçinemiyor. Yapay gündemlerle gününü dolduran bu iktidardan tamamen ümidini kesmiş. Çaresizlik duygusu, milletimin kaderi olmayacak!" (12 Mart)

"Uçacağız, kaçacağız derken, bir de baktık paramız pul, altınımız da teneke olmuş. Daha başka hangi ekonomik göstergeleri göstermemiz gerek?" (13 Mart)

"Ben ekonomiye ilişkin verileri söyleyince, Sayın Erdoğan çok kızıyor. "Türkiye ekonomisini 3,5 kat büyüttük." diyor. Türk Ekonomisi 3,5 kat büyüyebilmek içinse 15 kat borçlanmış. Nedense Sayın Erdoğan bunu hiç dile getirmiyor." (14 Mart)

"Bizim gibi yönetilen ülkeler; 1. Problemleri doğru tespit edemezler. 2. Doğru çözüm üretemezler. 3. Kaynaklarını verimli kullanamazlar. 4. Kesinlikle başarısız olurlar. Ve işte o nedenle bizim gibi yönetilen ülkelerin salgın paketinde konut kredisi indirimi olur." (29 Mart)

"Müşteri garantisi verilmiş havaalanları, yollar, köprüler, tüneller salgından ötürü bomboş ama beyefendilerin ödemesi yapılmaya devam ediyor. Mücbir sebep koşullarını işletin, üç ay boyunca bunlara para ödemeyin.” (30 Mart)

"Zorunlu karantina uygulanırsa işine gidemeyen, aç kalmış milletimizin giderlerini iktidar olarak ödemek zorundalar. Anlaşılıyor ki ekonomik mecburiyetten kurtulmak amacıyla bunu yapmayacaklar." (1 Nisan)

"Sayın Erdoğan 25 milyar Avroluk ekonomik destek paketi açıklayan İspanya'ya yardım uçağı, 35.000 dolar geliri olan İtalyanlara yardım gemisi, Türk Milleti'ne ise televizyondan IBAN gönderiyor." (2 Nisan)

"İktidardakilere öneriyoruz. Kendini ekonomi alanında kanıtlamış uzmanlarca hazırlanmış çözüm önerilerimiz var. Alın, kullanın. Toplumun tüm kesimlerini kapsayıcı, ülkemizi en az hasarla düze çıkaracak bir ekonomik programı bir an önce hazırlayın." (22 Nisan)

"Kepenk kapatmış esnaflarımızın istihdamlarını garanti altına alabilmek, yarınlarını kurtarabilmek için, çalışan başına devletin 10.000 TL destek vermesini ve bunun bir yılının da geri ödemesiz olmasını öneriyoruz.” (2 Mayı)

\section{Recep Tayyip Erdoğan'ın Söylemleri}

"Ekonomik İstikrar Kalkanı Paketi ile KOVID-19 salgınının etkilerini azaltmak için toplamda 100 milyar liralık bir kaynağı devreye alıyoruz." (18 Mart)

"İlk günden itibaren Koronavirüs salgınına karşı tüm kurumlarımız ve imkanlarımızla Milletimizin yanında yer aldık. Tedbirlerle ve ekonomik destek paketleriyle vatandaşlarımızı bu krizin etkilerinden korumaya devam edeceğiz. Biz güçlü bir Milletiz, hep birlikte başaracağız." (25 Mart)

"Koronavirüs salgınının, insan hayatını ve ekonomik istikrarı olumsuz etkilediği sancılı bir dönemden geçiyoruz. İnsanlığın tamamı rahat bir nefes alıncaya kadar bu küresel sağlık kriziyle tüm ülkeler ortak mücadele yürütmelidir.” (26 Mart)

"İstihdamı korumak, gelirini kaybeden vatandaşlarımıza sahip çıkmak, emeklilerimize destek vermek, esnafi ve sanatkarı ayakta tutmak, üretimi desteklemek için her önlemi alıyoruz. Attığımız ve atacağımız adımlarla hiçbir kesimi sahipsiz bırakmamakta kararlıyız." (13 Nisan) 
"Son 18 yılda demokraside ve ekonomide kat ettiğimiz büyük mesafe, geleceğimize güvenle bakmamızda en önemli güç ve moral kaynağımızdır." (28 Mayıs)

\section{13. Emeklilikte Yaşa Takılanlar}

Emeklilikte yaşa takılanlar, sigortalılık süresini doldurdukları ve prim şartını sağladıkları halde getirilen yaş şartı nedeniyle emekli olamayanları tanımlamaktadır. Konuyu gündeme getiren Akşener, Erdoğan'ın "çift dikiş maaş” söylemini ve iktidarı eleştirmiştir.

\section{Meral Akşener'in Söylemi}

"EYT’lilerin sorunlarını "çift dikiş maaş" diye kestirip atınca, konu kapanmıyor, Sayın Erdoğan. Hakkını arayan bu insanlarımızla bir kerecik bile empati kurabildin mi?" (13 Mart)

\section{14. Irkçılık}

ABD'de siyahi George Floyd'un polis şiddeti sonucu hayatını kaybetmesi tepki çekmiş, gösteriler düzenlenerek polis şiddeti protesto edilmiştir. Bu konuda İngilizce tweet yayınlayan Erdoğan, bu 1rkçı yaklaşımın herkesi derinden üzdüğünü belirtmiştir.

\section{Recep Tayyip Erdoğan'ın Söylemi}

"The racist and fascist approach that led to the death of George Floyd in the US city of Minneapolis as a result of torture has not only deeply saddened all of us, but it has also become one of the most painful manifestations of the unjust order we stand against across the world." (29 May1s)

\section{15. İçişleri Bakanı Süleyman Soylu'nun İstifası}

Covid-19 salgınının yayılma hızını düşürmek için uygulanan sokağa çıkma yasağının halka geç duyurulduğu ve insanların sosyal mesafeye dikkat etmedikleri haberleri nedeniyle İçişleri Bakanı Süleyman Soylu görevinden istifa ettiğini açıklamış, istifası Cumhurbaşkanı Erdoğan tarafından kabul edilmemiştir. Bahçeli, istifanın mücadele ruhunu sekteye uğratacağını ifade ederek, istifanın kabul edilmemesine destek vermiştir. Bahçeli "kırılgan" ifadesiyle eğretileme yaparak, hassas bir dönemden geçildiğini belirtmiştir. İstifayı olumlu karşılayan Akşener, Ekonomi Bakanı ve Tarım Bakanı'nın da istifalarını beklediğini ifade etmiş ve başarısız olarak nitelendirerek eleştirmiştir. “Damat” ifadesiyle Ekonomi Bakanı'nı kasteden Akşener öznelleştirme yapmıştır.

\section{Devlet Bahçeli'nin Söylemi}

"Terörden ekonomiye, bölgesel sorunlardan küresel dayatmalara varıncaya kadar ülkemiz muazzam bir iradeyle duruş göstermektedir. Böylesi kırılgan bir dönemde İçişleri Bakanı Sayın Süleyman Soylu'nun istifa niyeti sürdürülen mücadele ruhunu sekteye uğratma riski taşımaktadır." (13 Nisan)

\section{Meral Akşener'in Söylemi}

"Hatayı ve başarısızlığı kabullenmek, sorumluluğunu üstlenmek olgunluk gerektirir. Sayın Süleyman Soylu'ya göstermiş olduğu olgun davranış nedeniyle teşekkür ediyorum. Aynı olgunluğu başarısızlıklarıyla birer marka haline gelmiş Damat'tan ve Tarım Bakanı'ndan da bekliyorum..." (12 Nisan)

\section{16. İktidar ve Muhalefet Çatışması}

Covid-19 ile mücadele döneminde de iktidar ve muhalefet çatışması devam etmiştir. Bahçeli, muhalefeti salgından siyasi rant elde etme peşinde koşmakla ve ülkeyi yıkmakla eleştirmiştir. Biz-öteki karşıtlığını kuran Bahçeli, muhalefeti iç ihanet cephesi olarak nitelendirmiş ve ötekileştirmiştir. Söylemlerinde eğretilemeler kullanan Bahçeli, "defolu siyasetçiler” ifadesiyle ilkesiz siyasetçileri, "kapı aralayacak" ifadesiyle olumsuz bir duruma sebep olunmasını, "avuçlarını 
yalayacaklar" ifadesiyle istediklerini elde edemeyeceklerini, "pusuya yatıyor" ifadesiyle ülke için olumsuz koşullar hazırlanıp beklendiğini, "aynı yemlikten beslenip" ifadesiyle aynı düşüncede olduklarını belirtmiştir. Bahçeli kullandığı düzdeğişmecelerde, "iç ihanet cephesi" ifadesiyle muhalefeti, "dış işgal cephesi" ifadesiyle uluslararası alanda Türkiye'nin sorun yaşadığı ülkeleri kastetmiştir. İktidarı eleştiren Kılıçdaroğlu, söyleminde kullandığı eğretilemelerde "kibir abideleri" ifadesiyle iktidarı, "Saray'ın beslemeleri" ifadesiyle iktidar yanlılarını kastetmiş ve biz-öteki karşıtlığını kurmuştur. Muhalefeti eleştiren Erdoğan, "laf üstüne laf koymanın değil, taş üstüne taş koymanın çabası" ifadesiyle eğretileme yaparak, icraat yapma çabasında olduklarını belirtmiştir. "Türkiye'nin tökezlemesini bekleyenler" ifadesiyle düzdeğişmece kullanan Erdoğan, muhalefeti kastederek biz-öteki karşılığı kurmuştur.

\section{Devlet Bahçeli'nin Söylemleri}

"Salgından siyasi rant elde etmenin peşinde koşan defolu siyasetçilere itibar hezeyan ve hüsran verici akıbetlere kapı aralayacaktır. Hastalıktan fayda uman, Türkiye'nin çöküşü ve toplumsal infiali için alavere dalavere içinde olanlar sadece avuçlarını yalayacaklardır." (7 Mayıs)

"Türkiye ne zaman ileri atılsa, ne zaman parlayıp öne çıksa muhakkak surette iç ihanet cephesi ile dış işgal cephesi el ele verip pusuya yatıyor, akabinde de saldırıya geçiyor. Bunlar ne vicdan dinliyor, ne insanlık biliyor. Aynı yemlikten beslenip, aynı yıkımı hedefliyorlar." (9 Mayıs)

\section{Kemal Kılıçdaroğlu'nun Söylemi}

“Bu kibir abideleri güçlerini nereden alıyor, nerelerden besleniyor! Saray'ın beslemeleri, beni iyi duyun!" (13 Nisan)

\section{Recep Tayyip Erdoğan'ın Söylemi}

"Biz laf üstüne laf koymanın değil, taş üstüne taş koymanın çabasındayız. 18 yılda verdiğimiz her sözü tuttuğumuz gibi, Koronavirüs salgınına karşı da milletimize verdiğimiz sözleri yerine getirecek, Türkiye'nin tökezlemesini bekleyenleri bir kez daha üzeceğiz." (12 Mayıs)

\section{17. İnfaz Düzenlemesi}

Muhalefetin itiraz etmesine rağmen, AKP ve MHP'nin TBMM'ye getirdiği infaz düzenlemesi kabul edilmiştir. CHP, infaz kanununun iptali için AYM'ye 22 Nisan tarihinde başvurusunu şekil yönünden, 11 Haziran tarihinde de esas yönünden yapmıştır. İktidar ve muhalefeti karşı karşıya getiren düzenlemeye Kılıçdaroğlu ve Akşener karşı çıkarken, Erdoğan düzenlemenin Meclis'te kabul edilmesi konusunda "Milletimize hayırlı olsun" ifadesini kullanmıştır. Kılıçdaroğlu, Erdoğan'ı af yasası hakkında söylemde bulunmamakla eleştirmiştir. İnfaz indirimi yasasını 'yanlış' olarak nitelendiren Akşener, iktidarı ve MHP'yi infaz yasası nedeniyle eleştirmiştir. Akşener, "küçük ortağı" ifadesiyle düzdeğişmece yaparak MHP'yi, "kırmızı çizgilerimiz" ifadesiyle eğretileme yaparak taviz vermeyecekleri konuları kastetmiştir. Erdoğan, infaz düzenlemesinin Meclis’te kabul edilmesini olumlu karşılamıştır.

\section{Kemal Kılıçdaroğlu'nun Söylemi}

"Her konuda konuşan Erdoğan, "af yasası" konusunda neden tek bir laf etmedi, neden hiç konuşmuyor?" (13 Nisan)

\section{Meral Akşener'in Söylemleri}

"Ak Parti ve küçük ortağının infaz yasasında; çocuk istismarı, kadına şiddet ve uyuşturucu satıcılığı için indirim var. Bunlar bizim kırmızı çizgilerimizdir. İnfaz yasasını milletimiz ile şeffaf şekilde paylaşın, kapalı kapılar arkasında oldu bittiye getirmeyin.” (3 Nisan) 
"Ak Parti ve küçük ortağının infaz indirimi yasasında; kadına şiddet, çocuk istismarı gibi kanayan yaramız olan suçlar da var. Bu yanlışa ortak olmayın! Çünkü bir kadını ağlatanın, bir çocuğu üzenin, vicdanları kanatanın \#AffıYok" (4 Nisan)

\section{Recep Tayyip Erdoğan'ın Söylemi} (14 Nisan)

“TBMM Genel Kurulu'nda kabul edilen yeni infaz düzenlemesi Milletimize hayırlı olsun.”

\section{18. İşşizlik}

İşsizlik konusuna değinen tek lider Akşener olmuştur. Akşener, vatandaşlara geri ödemesiz nakit yardımı yapılması, küçük esnaf, KOBİ’ler ve üretim yapan şirketlere ise destek verilmesi gerektiğini dile getirmiştir. İktidarı ekonomiyi konuşmamakla eleştiren Akşener, işsiz kalan insanlara devletin yardım etmekte geciktiğini belirterek iktidarın süreci iyi yönetemediğini ima etmiştir.

\section{Meral Akşener'in Söylemleri}

“İktidar ekonomiyi konuşmayı sevmese de, milletimize yaşatılan bu ekonomik kriz, Türk aile yapısını bozacak kadar derinleşiyor. İşsiz gençlerimiz evlenemiyor, evlerde huzur kalmıyor, insanımız gelecekten umudunu hızla kaybediyor." (13 Mart)

"En başından beri söylüyoruz, devletin vatandaşlarımıza geri ödemesiz nakit yardımı yapması gerekli. Emeklilerimiz, \#EYT'liler dahil, yevmiye ile çalışan, işsiz kalan insanlarımıza yardım etmek için daha ne bekliyorsunuz?" (2 Nisan)

"Büyük işletmelerin çalışan çıkarmadan süreci sürdürme sözleri son derece memnun edici. Devletimiz de süreç boyunca aynı özveriyi göstererek, finansal gücü olmayan küçük işletmelere ve çalışanlarına destek olmalı." (3 Nisan)

"İssizlik tahmin edilenden çok daha kötü. Salgın sonrası yeniden açılacak olan küçük esnaflarımızın, KOBI'lerimizin, ihracatçılarımızın, üretim yapan şirketlerimizin yaşaması ve personel istihdam edebilmeleri için her görüşten destek alınarak yardım programları oluşturulmalı." (30 Nisan)

\section{19. Karantina}

Virüsün yayılma hızı karantina uygulanmasını gerektirmiştir. Karantina konusuna söyleminde değinen Kılıçdaroğlu 'EvdeTut' başlık etiketiyle iktidarın önlem alması gerektiğini belirterek eleştirmiştir. Akşener, iktidarı karantina uygulamasını halka geç duyurmakla, krizi yönetememekle eleştirmiştir. 'DevletYönetmek' başlık etiketini de kullanarak, iktidarın devleti yönetemediğini ima etmiştir.

\section{Kemal Kılıçdaroğlu'nun Söylemi}

"Artık sorun "evde kal" aşamasından "evde tut" aşamasına geçmiştir. Bir an önce iktidarın bu önlemleri alması gerekmektedir. \#EvdeTut" (28 Mart)

\section{Meral Akşener'in Söylemleri}

"Tam karantina teklifimizi yasak başlangıcından 2 saat önce vatandaşa bilgi vererek uygulayan iktidar, bir kez daha kriz yönetiminde ne kadar acemi olduklarını ispatladı. Tüm vatandaşlarımızı sakin olmaya, yasağa uyarak kendilerini ve sevdiklerini korumaya davet ediyorum. \#EvdeKal" (11 Nisan)

"Sayın Erdoğan'ın canı "sokağa çıkma yasağı çekti” ve birden sokağa çıkma yasağı ilan edildi. Bilim yok, akıl yok, plan yok, program yok. Ciddiyet zaten hiç olmadı. Haftalardır salgına karşı milim milim aldığımız mesafe de iki saatte heba oldu! \#DevletYönetmek" (12 Nisan) 


\section{20. Memleket Masası Fikri}

Akşener'in salgın sürecinde Türkiye'nin birlik ve beraberliğini hedeflediğini söyleyerek ortaya koyduğu Memleket Masası fikrini, Bahçeli yanlış siyasetin yanlış zamanda dillendirildiği bir masa edebiyatı olarak değerlendirmiştir. "Mahsurlu odaklar" düzdeğişmecesiyle Memleket Masası fikrini savunanları kasteden ve ötekileştiren Bahçeli, "edebiyat" sözcügüyle eğretileme yaparak, Memleket Masası fikrinin faydasız olduğunu belirtmiştir. "Kırık dökük üç ayaklı bir masa" eğretilemesiyle de muhalefeti kastederek, muhalefetin bir araya gelmesinin sağlam temellere oturmadığını ima etmiştir. Akşener, "birlik fotoğrafı" düzdeğişmecesini kullanarak tüm partilerin bir araya gelmesini kastetmiştir.

\section{Devlet Bahçeli’nin Söylemi}

"Yanlış siyasetin yanlış zamanda dillendirdiği bir masa edebiyatı gündeme yerleşmiştir. Malum ve mahsurlu odaklar IP'in "Memleket Masası" kuralım teklifine önüne arkasına bakmadan bodoslama atlamışlardır. Halbuki kırık dökük üçayaklı bir masa zaten kurulmuştur." (11 Mayıs)

\section{Meral Akşener'in Söylemleri}

“Siyasi kimliğim baki kalmak üzere, Türk Milleti'nin geleceğini düşünen siyasi parti liderlerine çağrı yapıyorum. Gelin ortak aklı işleterek hep birlikte "Memleket Masası" etrafında toplanalım. Türkiye'nin birliğinin ve beraberliğinin resmini dünyaya sergileyelim." (10 Mayıs)

“"Memleket Masası”nda ortak akılla alınacak doğru kararlar, millet olarak hepimize fayda sağlar; yurt dışına karşı da birlik ve beraberlik mesajı olur. Çağrımız bunun içindir." (12 Mayıs)

"Madem yurt dışından, Londra'daki finans çevrelerinden ekonomimize saldırıyorlar, gelin tüm siyasi partiler hep birlikte "Memleket Masası" etrafinda buluşalım. Böyle bir birlik fotoğrafinın Türkiye'ye ne zararı olur?" (16 Mayıs)

\section{21. Milli Dayanışma Kampanyası}

İhtiyaç sahiplerine destek amacıyla Cumhurbaşkanı Erdoğan tarafından başlatılan Milli Dayanışma Kampanyası'na Bahçeli destek verirken; Kılıçdaroğlu, açılan bağış kampanyasına Tekalifi Milliye Emirleri'nin örnek verilmesini eleştirmiş ve iktidarın ülkeyi yönetemediğini belirtmiştir. Erdoğan ise destek çalışmalarına devletin öncülük etmesini gerekli gördüklerini aktarmıştır.

\section{Devlet Bahçeli’nin Söylemi}

"Bugün akşam Sayın Cumhurbaşkanımızın konuşmasını dikkatle takip ettim. "BİZ BİZE YETERIZ" diyerek başlattığı "MILLİ DAYANIŞMA KAMPANYASI" hakikaten takdir ve tebrike layıktır. Sayın Cumhurbaşkanımıza gönülden teşekkür ediyorum.” (30 Mart)

\section{Kemal Kılıçdaroğlu'nun Söylemi}

“Açılan bağış kampanyasına Tekalifi Milliye Emirleri'ni örnek vermek, Türkiye Cumhuriyeti tarihini bilmemenin sonucudur. Acı olan ise bunu Türkiye'yi yönettiğini düşünenlerin dillendirmesidir. Ne diyorduk, "Türkiye yönetilmiyor, Türkiye savruluyor." " (4 Nisan)

\section{Recep Tayyip Erdoğan'ın Söylemi}

“İhtiyaç sahiplerine destek çalışmalarına devletin öncülük etmesi gerektiğini gördüğümüz için MILLI DAYANIŞMA KAMPANYASI'nı başlatıyoruz. Kampanyayı 7 aylık maaşımı bağışlayarak açıyorum.” (30 Mart)

\section{22. Olağanüstü Hal İlanı}

Virüsün yayılmasını ve can kaybını önlemek için vatandaşlara 'evde kal' çağrıları yapılmıştır. Akşener, olağanüstü hal ilan edilmesini ve gerekli kritik adımların atılmasını 
savunmuş, hükümeti bu kararları almadığ için eleştirmiştir. Sağlık Bakanı'nın söylemlerini “üstü kapalı" olarak değerlendiren Akşener, yan anlam düzeyinde Sağlık Bakanı'nın Erdoğan'ın söylemlerinden farklı bir fikri ifade edemeyeceğini ima etmiştir. Akşener "tek kişi" ifadesiyle de düzdeğişmece kullanarak Erdoğan'ı kastetmiştir.

\section{Meral Akşener'in Söylemleri}

"Bilim Kurulu OHAL diyor, Sağlık Bakanı mecburen üstü kapalı aynı şeyi söylüyor. Ama tek kişinin iki dudağına bakan bu sistemde, işi ehline teslim edip, salgınla ilgili gerekli kritik adımlar atılamıyor...” (28 Mart)

“Adına ne derseniz deyin, OHAL'i uygulaması gereken vatandaş değil, hükümettir. Çünkü hükümet sokağa çıkma yasağı ilan ettiği zaman, devlet evde kalan herkesin giderlerini telafi etmek zorundadır. Vatandaş kendi OHAL'ini ilan edince, böyle yükümlülük yok. İşte bu yüzden kaçıyorlar." (29 Mart)

\section{23. Rusya'yla Dış İlişkiler}

Cumhurbaşkanı Erdoğan ve Rusya lideri Putin arasında 5 Mart 2020 tarihinde gerçekleşen görüşme sonrasında İdlib Mutabakatı üzerinde uzlaşmaya varılmıştır. Akşener, hükümetin Rusya ile dış ilişkilerdeki tavrını eleştirmiştir. Akşener, "kapısında bıraktın" ifadesiyle eğretileme yaparak, diş ilişkilerde taviz verildiğini kastetmiştir.

\section{Meral Akşener'in Söylemi}

"Tarihimizde savaşlar kaybettik ama hiçbir zaman onurumuzu kaybetmedik. Rusya'ya giderken senden, Mehmetçik kadar cesur ve onurlu olmanı bekledik; ama sen gittin, onurumuzu Putin'in kapısında biraktın, geldin." (11 Mart)

\section{24. Sağlık Çalışanları}

Tüm dünyada olağanüstü bir dönemden geçilirken, sağlık personelinin çalışmaları alkışlanmıştır. Sağlık çalışanlarını söylemlerinde ifade eden tüm liderler olumlu tweetler paylaşmışlardır. Sağlık çalışanlarının fedakarca çalıştı̆̆ını dile getiren Bahçeli, "vahim bir uçurum" eğretilemesini kullanarak salgınla mücadelede sürekliliğin olmaması halinde felaket bir sonuçla karşılaşılacağını belirtmiştir. Akşener, virüsle mücadelede hayatını kaybeden sağlık çalışanlarının şehit ilan edilmesi gerektiğini bildirmiştir. Erdoğan, sağlık çalışanlarını fedakar kahramanlar olarak nitelendirmiş, "göğüs geren" eğretilemesiyle sağl1k personelinin zorlu mücadele içinde olduğunu belirtmiştir.

\section{Devlet Bahçeli'nin Söylemleri}

"Doktorlarımızı, hemşirelerimizi, bütün sağlık çalışanlarımızı, aynı şekilde güvenlik güçlerimizi gönülden selamlıyor, hepsini muhabbetle alkışlıyorum. Allah hepsinden razı olsun diyorum. KOVID-19 hastalığından vefat edenlere rahmet, tedavi edilenlere de şifa diliyorum.” (21 Mart)

"Sağlık Bakanlığımız gece demiyor, gündüz demiyor. Sağlık çalışanlarımız fedakarca, adanmış ve anıtlaşmış şekilde salgınına engel olmaya gayret ediyor. Kazanımlarımız boşa çıkarsa, aman sende denirse, Türkiye vahim bir uçuruma savrulacaktır." (7 Mayıs)

\section{Meral Akşener'in Söylemi}

“Salgınla mücadele ederken Covid-19'a yakalanıp vefat eden tüm sağlık çalışanlarımızın ayrım yapmaksızın şehit ilan edilmesi gerekir. Çünkü onlar da, tıpkı Mehmetçiğimiz gibi, bizler yaşayalım diye kendilerini tehlikeye atıoorlar." (30 Mart) 


\section{Recep Tayyip Erdoğan'ın Söylemleri}

"Koronavirüsle mücadelede takdire şayan bir fedakarlıkla ve sabırla görev yapan tüm sağlık personelimize şükranlarımı sunuyorum. Allah'ın yardımı, Milletimizin desteğiyle bu süreci de güçlenerek atlatacağız.” (19 Mart)

"Koronavirüs ile mücadelemizin özverili ve fedakar kahramanlarına, her türlü zorluğa ve sıkıntıya göğüs geren tüm sağlık çalışanlarımıza şahsım, ailem ve Milletim adına selamlar, sevgiler ve elbette alkışlar..." (20 Mart)

\section{25. Sosyal Mesafe}

Covid-19 virüsü ile mücadele sosyal mesafe kavramını ortaya çıkarmış, tüm siyasiler sosyal mesafeye uyulması konusunda ortak görüş ifade ederek uyarılarda bulunmuşlardır. Sosyal mesafenin elzem olduğunu vurgulayan Bahçeli, "geceyi gördük, güneşi de göreceğiz" eğretilemesiyle salgın konusunda karşılaşılan zorlukların aşılacağını, "felakete altın yaldızlı davetiye uzatmak" eğretilemesiyle de sosyal mesafeye ve alınan tedbirlere uyulmaması halinde salgının tahmin edilenden daha hızlı bir şekilde yayılacağını ifade etmiştir. Akşener ve Erdoğan da sosyal mesafenin korunmasının önemine değinmişlerdir.

\section{Devlet Bahçeli'nin Söylemleri}

"Sosyal izolasyonla, evde kalarak, birbirimize dayanarak, yardımlaşma kanallarını aktifleştirerek, karamsarlığı kovarak virüs karanlığını bertaraf edeceğiz. Zamanı geldiğinde hayat normalleşecek, birbirimizle kucaklaşacağız. Dayan milletim, geceyi gördük, güneşi de göreceğiz." (27 Mart)

"Alınan tedbirleri yok saymak, rehavete kapılmak hepimizi acıklı sonuçlara mahkum edecektir. Maske takmak şarttır, sosyal mesafe elzemdir. Nasılsa her şey düzeliyor, salgın bitiyor acemiliği ve aceleciliğiyle davranış sergilemek felakete altın yaldızlı davetiye uzatmaktan farksızdır." (7 Mayıs)

"Küresel düzeyde hüküm süren hastalık sosyal mesafeleri genişletirken, düşünce kalıplarını, duygu kalibrelerini, duyuş ve duruş kalitelerini fazlasıyla etkilemektedir. Buna yönelik hazırlık yapan, geleceğin ufkunu basiretle analiz eden ülkeler diğerlerine fark atacaktır." (14 May1s)

\section{Meral Akşener'in Söylemi}

"Koronavirüse karşı fiziki mesafemize dikkat edelim, birbirimizin hayatını koruyalım. Sosyal mesafeni koru, \#TürkiyeyiKoru" (10 Nisan)

\section{Recep Tayyip Erdoğan'ın Söylemi}

"Kontrol altında tutamayacağımız her türlü temas, bizi virüs taşıyıcısı haline getirebilir. Sosyal mesafeyi ne kadar korur ve sosyal hareketliliği ne kadar azaltırsak, virüsün yayılma hızını, dolayısıyla yol açtı̆̆ tehdidi o derece düşürürüz." (18 Mart)

\section{26. Şehir Hastaneleri}

Salgın sürecinde sağlı sistemiyle ilgili olarak hastane sayısı, yatak kapasitesi ve solunum cihazı sayısının yeterliliği gündeme gelmiştir. Erdoğan söylemlerinde inşa edilen ve hizmete açılan şehir hastaneleri hakkında bilgi vermiştir.

\section{Recep Tayyip Erdoğan'ın Söylemleri}

"Şehir Hastaneleri ile ülkemize her türlü imkanı içerisinde barındıran modern sağlık merkezleri kazandırdık. 2.682 yataklı İkitelli Şehir Hastanesi’nin ilk etabını 20 Nisan'da hizmete 
alıyoruz. Diğer hastanelerimizi de süratle tamamlayarak Milletimizin hizmetine sunacağız." (2 Nisan)

"Dünyanın Koronavirüs salgınıyla adeta kavrulduğu günlerde Şehir Hastanelerimizi açıyor olmamız oldukça önemlidir. Bugün ilk etabını hizmete aldığımız Başakşehir Şehir Hastanemiz Milletimize hayırlı uğurlu olsun." (20 Nisan)

"Yeşilköy ve Sancaktepe'de toplam 2 bin yatak kapasiteli iki hastanemizin yapımı hızla devam ediyor. Projeleri inşallah en kısa sürede tamamlayarak İstanbul'a gerçek manada iki önemli kalıcı hastane kazandırmış olacağız." (3 Mayıs)

"Başakşehir Çam ve Sakura Şehir Hastanesi, kaliteli ve kapsayıcı sağlık hizmetinin değerinin çok daha iyi anlaşıldığı bir dönemde Türkiye'nin marka eserlerinden biri olacaktır. Ülkemize ve milletimize hayırlı olmasını diliyorum.” (21 Mayıs)

"Söz verdiğimiz gibi çok kısa bir süre içerisinde tamamladığımız Sancaktepe Prof. Dr. Feriha Öz Acil Durum Hastanemizi bugün hizmete alıyoruz. Ülkemize, milletimize hayırlı uğurlu olsun." (29 May1s)

"Pek çok ülkenin geçici sahra ve prefabrik hastaneler kurarak çözmeye çalıştığı sorunu biz çok daha kısa sürede kalıcı hastaneler inşa ederek aşmayı başardık. Ülkemizin yüz akı hastanelerimiz ve güçlü altyapımızla sağlıkta çok daha ciddi bir sıçrama gerçekleştireceğiz." (31 May1s)

\section{27. Tarım}

Salgın sürecinde temel ihtiyaç olan gıdaya erişimde sıkıntı yaşanmaması tarımın önemini gündeme getirmiştir. Tarım konusunun önemine Bahçeli ve Akşener söylemlerinde yer vermişlerdir. Gıda güvenliğinin önemine değinen Bahçeli, "zirvesine tırmanmış" eğretilemesi ile gıda güvenliğinin öncelikli olmasını ifade etmiştir. Akşener ise gıdaya erişimin en stratejik alan olduğunu vurgularken, tarım alanı olan Çarşamba'ya yapılmak istenen Biyokütle Enerji Santrali'ne tepki göstermiştir. Tarımda alınacak önlemler konusunda iktidarı işbirliğine davet etmiştir.

\section{Devlet Bahçeli'nin Söylemleri}

"Hem ülkemizin hem de tüm dünyanın akut meselesi makroekonomik göstergelerin iyileşmesi değil, insan ve toplum sağlığını güvenceye almakla birlikte gıda ve hayat güvenliğini sağlamaktır. KOVID-19 yeni bir dünyanın kilitlerini açmış, yeni bir kavrayışın temellerini atmıştır." (9 Mayıs)

"Beşeriyetin öncelikleri, ihtiyaçlar hiyerarşisi değişim kulvarındadır. Her şeyden önce insan sağlığıyla birlikte gıda güvenliği önem piramidinin zirvesine tırmanmıştır. Tarım istikbalin, hatta istiklalin temincisidir. Toprağın bereketi birlik, dirlik ve güvenliğin farikasıdır." (14 Mayıs)

\section{Meral Akşener'in Söylemleri}

"Bu salgın sonrası, önümüzdeki dönemde dünyadaki en stratejik alan gıdaya erişim olacak. Artık ithalatı bırakıp kendi kendini doyurabilmek, ülkemizin birinci önceliği olmak zorunda. Bunun için de tarım merkezli bir üretim programını acilen hayata geçirmeliyiz." (3 Nisan)

"Ülkemizin en verimli tarım alanlarından biri olan Samsun Çarşamba'ya, milletimizin sağlığı hiçe sayılarak yapılmak istenen Biyokütle Enerji Santrali (BES), gözünü rant bürümüşlerin doğamıza ettikleri ihanettir. \#ÇarşambaBESeKarşı" (23 Mayıs)

"Ege ve Akdeniz bölgelerimizdeki yaşanan doğal afetler sonucu, tarımda karşı karşıya kaldığımız acil duruma karşı, iktidarı hazırladığımız bu dört maddelik önlem paketini acil olarak devreye sokmaya çağırıyorum.” (31 Mayıs) 


\section{28. YKS'nin Ertelenmesi}

Yükseköğretim Kurumları Sınavı salgın nedeniyle önce Temmuz ayına ertelenmiş, daha sonra tarih öne çekilerek 27-28 Haziran tarihlerinde yapılması kararlaştırılmıştır. Turizm sezonunun başlamasının, sınav tarihinin öne çekilmesinin nedeni olduğu iddia edilmiştir. Sınav tarihinin öne çekilmesini K1liçdaroğlu ve Akşener eleştirmiştir. Kılıçdaroğlu gençlerin umutlarının çalındığını ifade etmiş, "kulak tıkamak" eğretilemesiyle sınava girecek gençlerin taleplerinin dikkate alınmadığını belirtmiştir. Akşener, sınavın ertelenmesini plansız kriz yönetim anlayıșı olarak değerlendirerek, iktidarı eleştirmiş ve "faturasını gençlerimize, gelecekleriyle ödetmek" eğretilemesiyle sorumluluğun gençlere yüklendiğini ifade etmiştir. Erdoğan, sınav süresinin arttırıldığını ve barajın 10 puan düşürülerek 170'e çekildiğini duyurmuştur.

\section{Kemal Kılıçdaroğlu'nun Söylemi}

“Temmuz ayına ertelenen YKS'nin öne alınarak Haziran'da yapılacak olmas1; gençlerimizin geleceklerini ve umutlarını çalmak, emeklerini boşa çıkarmak, onlara kulak tıkamaktır! Gençlerimizin hayallerini çalmayın! \#yks2020" (5 Mayıs)

\section{Meral Akşener'in Söylemleri}

"İktidarın plansız, programsız, ciddiyetsiz kriz yönetim anlayışının faturasını gençlerimize, gelecekleriyle ödetmek vicdansızlıktır. \#ykstarihinedokunma" (1 Mayıs)

"Yandaşının bir dediğini iki etmeyen iktidar; gencine gelince 2 milyon tweet'i görmedi, duymadi. Yazıklar olsun. \#yks2020" (4 May1s)

\section{Recep Tayyip Erdoğan'ın Söylemi}

“\#yks2020, ilk açıklandığı tarihten 1 hafta sonrasına ertelendi. Ancak bu sınavda müfredattaki önemli bir kısımdan muaf olacaksınız. Ayrıca sınav süresini de artırdık. Bunun yanında baraj1 10 puan düşürerek 170'e çektik. Bu yılki maraton inşallah çok daha rahat geçecek." (5 May1s)

\section{29. Yurtdışı Yardımları}

Dünyanın böyle bir salgına hazırlıksız yakalanması, sağlık sistemindeki eksiklikleri gün yüzüne çıkarmıştır. Türkiye diğer ülkelere uçaklarla yardım malzemesi göndermiştir. İktidar ve muhalefet yurtdışı yardımları konusunda da uzlaşmamıştır. Akşener vatandaş maske bulamazken yurtdışına yardım gönderilmesini eleştirirken, Erdoğan bu yardımların imkan değil vicdan meselesi olduğunu belirtmiştir.

\section{Meral Akşener'in Söylemi}

"Vatandaşımız maske bulamazken yurt dışına yapılan yardımlar ülkemizin itibarı için değil, Sayın Erdoğan'ın uluslararası imajı için yapılıyor. Bir de üstüne ABD’ye, Irak'a gönderilen yardımlar pkk'ya, pyd'ye gidiyor." (3 Mayıs)

\section{Recep Tayyip Erdoğan'ın Söylemi}

“\#MilliTeknolojiHamlesi ile geliştirdiğimiz solunum cihazları Somalili kardeşlerimize nefes olacak. Medeniyet imkan değil, vicdan meselesidir. Milletimizin imkanları da vicdanı da mazlum ve muhtaçların yanındadır. Aziz Milletim, senin kalbinde merhamet adlı bir çınar vardır!" (2 Mayis)

\section{Sonuç}

Covid-19 salgını 2019 yılının sonunda Çin'de ortaya çıkarak tüm dünyayı etkilemiştir. En başta sağlık olmak üzere eğitim, ekonomi siyaset gibi alanları etkilemiş, sosyal hayatta dönüşümü zorunlu hale getirmiştir. Virüsün ortaya çıkışı konusundaki çelişkili açıklamalar tartışmaları 
beraberinde getirmiştir. Virüs için bir tedavinin ve aşının olmaması hızla yayılmasına neden olmuştur. Ülkelerin sağlı sistemlerinin böyle bir salgına karşı hazırlıklı olup olmadığı yönündeki tartışmalar sürerken, hasta sayısında ve can kaybında artışlar olmuştur. Küreselleşmenin etkisiyle daha hızlı yayılabilme ortamı bulan virüsün yayılma hızını düşürmek için ülkelerin sınırlarını kapatması ve uçuşları yasaklaması alınan öncelikli tedbirler olmuştur. Salgınla mücadelede ilerleyen süreçte karantina kararları alınmış, sosyal mesafeye dikkat edilmesi ve maske takılması uyarılarında bulunulmuştur.

Türkiye, Covid-19 salgını ile mücadelede erken önlem alan ülkelerden birisi olmuştur. Türkiye'de ilk vakanın görüldüğü 11 Mart tarihi itibariyle Sağlık Bakanı Fahrettin Koca'nın açıklamaları ve yönlendirmeleri, Bilim Kurulu'nun oluşturulması ve Bilim Kurulu üyelerinin halkı bilgilendirmesi sürecin daha iyi yönetilmesini sağlamıştır. Salgınla mücadele için 20 yaş altı ve 65 yaş üstü vatandaşlara sokağa çıkma yasağı, 30 Büyükşehir ve Zonguldak iline giriş çıkış yasağı, 10 Nisan'dan 6 Haziran'a kadar hafta sonları sokağa çıkma yasağı getirilmiştir. Vaka sayısında düşüşün görülmesi ve iyileşen hasta sayısının yeni vaka sayısını geçmesiyle normalleşme adımları atılmaya başlanmıştır. Normalleşme adımlarında 1 Haziran tarihi esas alınmıştır.

Siyasi liderlerin de salgınla mücadelede uygulamaya koydukları politikalar ve söylemler dikkatle takip edilmiştir. Liderlerin kitleleri etkileme gücü olduğundan, söylem seçkini olan siyasi liderlerin söylemleri bu mücadele sürecinde önemli hale gelmiştir. Bu dönemde de liderler Twitter üzerinden mesajlarını vererek etki yaratmayı amaçlamışlardır. Siyasi liderler sosyal medya hesapları üzerinden doğrudan mesajlarını kitleye iletmişlerdir. Siyasetçilerin sosyal medya hesapları aracılığıyla gerçekleştirdikleri siyasal iletişim zaman ve mekan kavramlarını anlamsızlaştırmakta ve iletişimi aracısız hale getirmektedir. Yeni medya alanı siyasal iletişimde siyasetçilere eşit koşullarda kendilerini ifade etme olanağ 1 sunmakta, farklılık siyasi aktörlerin kişilik özellikleri, partileri, sosyal medyadaki konumları ve etki oranları ile ortaya çıkmaktadır. Twitter'da sınırlı sayıda karakter kullanarak kısa söylemlerle istenilen mesajın daha fazla kitleye ulaşması amaçlanmaktadır. Twitter'ın takipçi ve takip edilen özelliği, yanıtlar, beğeniler ve retweetler ile bir topluluk oluşturulabildiğinden gündem üzerinde etkili olunabilmekte ve ideolojik güç mücadelesi Twitter üzerinden devam edebilmektedir. Bu iktidar mücadelesinin aktörleri olan liderlerin mesajlarının okunması, söylemlerinin takip edilmesi siyasete yön vermektedir.

$\mathrm{Bu}$ çalışmada Covid-19 salgını sürecinde siyasi parti liderlerinin 11 Mart ve 1 Haziran tarihleri arasında Twitter'da paylaştıkları söylemlerinin gündemi nasıl etkilediği konu edinilmiştir. $\mathrm{Bu}$ zaman aralığında liderlerin tweetleri incelendiğinde Twitter'ı kullanım pratikleri şöyle gözlenmiştir. Bahçeli, diğer liderlere göre Twitter'da daha seyrek olarak mesaj paylaşmakta, fakat paylaştığı mesajları uzun bir tweet dizisi halinde belirli bir konu etrafinda aktarmaktadır. Kılıçdaroğlu söylemlerini daha kısa cümlelerle Twitter' da paylaşmakta ve mesajlarını o güne dair olan kutlama, anma, başsağlığı gibi konularla aynı tweette ifade etmektedir. Çalışma kapsamına o güne dair olan kutlama, anma, başsağlığı gibi konularla ilgili tweetler alınmadığından Kılıçdaroğlu'nun tweetleri diğer liderlere göre çalışmada daha az sayıda kullanılmıştır. Twitter'ı en aktif kullanan lider olan Akşener, çok farklı konularda eleştirel tweetler paylaşmaktadır. Erdoğan belirli konularda ağırlıklı mesaj paylaşmakta ve aynı konuyu farklı günlerde tweet olarak paylaşmaktadır.

Liderlerin 11 Mart-1 Haziran aralığında değindikleri konular şunlar olmuştur: $3600 \mathrm{ek}$ gösterge, adalet, basının bilgilendirme işlevi, basın özgürlüğü, belediyelerin yardım kampanyaları, Bilim Kurulu, camide şarkı çalınması, Covid-19, Cumhurbaşkanlığı Hükümet Sistemi, darbe iması, eğitim, ekonomi, emeklilikte yaşa takılanlar, ırkçılık, İçişleri Bakanı Süleyman Soylu'nun istifası, iktidar ve muhalefet çatışması, infaz düzenlemesi, işsizlik, karantina, Memleket Masası fikri, Milli Dayanışma Kampanyası, olağanüstü hal ilanı, Rusya'yla dış ilişkiler, sağlık çalışanları, sosyal mesafe, şehir hastaneleri, tarım, YKS'nin ertelenmesi, yurtdışı yardımları. 
Tüm liderler Covid-19 salgını ve ekonomi konusuna tweetlerinde değinmiştir. Liderler Covid-19 salgını ile mücadele konusunu vurgulamış ve olumlu, yapıcı mesajlar paylaşmışlardır. Salgının ekonomiye olumsuz etkisi nedeniyle iktidar ekonomik destek paketlerini gündeme getirirken, muhalefet ekonomi politikalarını eleştirmiştir. Bilim Kurulu, karantina, sağlık çalışanları ve sosyal mesafe konularında tüm liderler olumlu ve yapıcı tweetler paylaşmışlardır. Darbe iması konusunda Kılıçdaroğlu ve Erdoğan darbeye karşı olduklarını ifade ederken, karş1 siyasi görüşü ötekileştirmiş ve karşıt görüşü darbeyi savunmakla itham etmişlerdir. Basın özgürlüğü, belediyelerin yardım kampanyaları, infaz düzenlemesi ve YKS'nin ertelenmesi konularında muhalefet iktidarı eleştirmiştir. Muhalefet, basına verilen cezaları, belediyelerin yardım kampanyalarının valilik iznine bağlanmasını, infaz düzenlemesinin kabul edilmesini ve YKS'nin tarihinin öne çekilmesini doğru bulmadığını ifade etmiştir. Milli Dayanışma Kampanyası'nı iktidar desteklerken, muhalefet Tekalifi Milliye Emirleri'nin örnek verilmesini ve kampanya için televizyondan IBAN paylaşılmasını eleştirmiştir. Tarım konusunda Bahçeli gıda güvenliğini, Akşener ise tarımsal alanların korunmasını ifade ederek benzer fikirler paylaşmışlar, fakat Akşener'in ortaya koyduğu Memleket Masası fikrinde ve İçişleri Bakanı Süleyman Soylu'nun istifası konusunda uzlaşamamışlardır. Yurtdışı yardımları konusunda Akşener, Erdoğan'1 eleştirmiştir. Adalet konusunda Akşener adaletin olmadığını ifade ederken, Erdoğan Türkiye'nin bir adalet devleti olduğunu belirtmiştir. Bahçeli, basının bilgilendirme işlevi, Bilim Kurulu ve Cumhurbaşkanlığı Hükümet Sistemi temalarına değinen tek lider olurken, camide şarkı çalınması temasına değinen tek lider Kılıçdaroğlu olmuştur. Akşener, 3600 ek gösterge, eğitim, emeklilikte yaşa takılanlar, işsizlik, olağanüstü hal ilanı ve Rusya'yla dış ilişkiler temalarına değinen tek lider olurken, 1rkçılık ve şehir hastaneleri temalarına değinen tek lider Erdoğan olmuştur.

Siyasi liderler paylaştıkları tweetlerde salgınla doğrudan ilgili konularda uzlaşmacı ve yapıcı söylemlerde bulunurken, salgının dolaylı olarak etkilediği alanlarla ilgili konularda iktidar ve muhalefet konumlarını sürdürmüş, ötekileştirmeler ve kurulan karşıtlıklarla birbirine zıt söylemler ifade etmişlerdir. Liderler söylemleriyle salgınla mücadele konusunda kamuoyunu bilgilendirici mesajlar verirken, dayanışma ve birliğin önemine değinmişlerdir. Ekonomi, belediye yardımları, darbe, infaz düzenlemesi, Memleket Masası fikri, Milli Dayanışma Kampanyası ve YKS'nin ertelenmesi konularında ise kamuoyunu kendi partilerinin savundukları düşünceler doğrultusunda etkilemeye, bunu da siyasi karşıtlık üzerinden gerçekleştirmeye çalışmışlardır.

\section{Kaynakça}

ABD'den sonra şimdi de Fransa: Paris'te sokaklar karıştı. (2020, 20 Nisan). https://www.cnnturk.com/dunya/abdden-sonra-simdi-de-fransa-pariste-sokaklarkaristi?page $=1$ Erişim tarihi: 9 Eylül 2020.

Aydoğan, A. \& Başaran, F. (2012). "Yeni medyayı alternatif medya bağlamında anlamak". Alternatif medya alternatif gazetecilik. Ö. Özer (Ed.). Literatürk Yayınları. 213-246.

Atabek, Ü. (2003). "Yeni iletişim teknolojileri ve yerel medya için olanaklar". Yeni iletişim teknolojileri ve medya. S. Alankuş (Der.). IPS İletişim Vakfı Yayınları. https://doi.org/10.31123/akil.441825

Bilgin, N. (2006). Sosyal bilimlerde içerik analizi teknikler ve örnek çalışmalar. 2. Baskı. Siyasal Kitabevi.

Çöl, M. \& Güneș, G. (2020). “COVID-19 salgınına genel bir bakıș”. Covıd-19. K. O. Memikoğlu \& V. Genç. (Ed.). Ankara Üniversitesi Basımevi. 1-8. http://www.medicine.ankara.edu.tr/wp-content/uploads/sites/121/2020/05/COVID-19-

Kitap.pdf Erişim tarihi: 31 Mayıs 2020. https://doi.org/10.5222/ankem.2020.025

Devran, Y. (2010). Haber söylem ideoloji. Başlık Yayın Grubu. 
Erzen, M. Ü. (2009). "Duygusal zeka yetisinin siyasal aktörlerin performanslarına etkisi”. Siyasetin iletişimi. A. Özkan (Ed.). Tasam Yayınları. 193-210.

Fiske, J. (2003). İletişim çalışmalarına giriş. S. İrvan (Çev.). 2. Basım. Bilim ve Sanat Yayınları.

Gökçe, O. (2006). İ̧erik analizi kuramsal ve pratik bilgiler. Siyasal Kitabevi.

Guerrero-Solé, F. (2018). "Interactive behavior in political discussions on Twitter: Politicians, media, and citizens' patterns of interaction in the 2015 and 2016 electoral campaigns in Spain". 1-16. https://journals.sagepub.com/doi/pdf/10.1177/2056305118808776 Erişim tarihi: 5 Haziran 2020. https://doi.org/10.1177/2056305118808776

Hermann, M. G., Sakiev, A. \& Smith, M. (2010). "Governance in context: Understanding the ingredients of political leadership". https://papers.ssrn.com/sol3/papers.cfm?abstract_id=1642578 Erişim tarihi: 5 Haziran 2020.

https://Twitter.com/dbdevletbahceli

https://Twitter.com/kilicdarogluk

https://Twitter.com/meral_aksener

https://Twitter.com/rterdogan

İnceoğlu, Y. G. \& Çomak, N. A. (2009). “Teun A. van Dijk”. Metin çözümlemeleri. Y. G. İnceoğlu, N. A. Çomak (Ed.). Ayrıntı Yayınları. 19-79.

Jones, P. (2003). "Strategic leadership: The platform for political success". Economic Development Institute Information Booklet Series II. https://papers.ssrn.com/sol3/papers.cfm?abstract_id=882206 Erişim tarihi: 5 Haziran 2020.

Keller, T. R. \& Kleinen-von Königslöw, K. (2018). "Followers, spread the message! Predicting the success of Swiss politicians on Facebook and Twitter". 1-11. https://journals.sagepub.com/doi/pdf/10.1177/2056305118765733 Erişim tarihi: 5 Haziran 2020. https://doi.org/10.1177/2056305118765733

Kışlalı, A. T. (2010). Siyaset bilimi. 14. Baskı. İmge Kitabevi Yayınları.

Masroor, F., Khan, Q. N., Aib, I. \& Ali, Z. (2019). "Polarization and ideological weaving in Twitter discourse of politicians". https://journals.sagepub.com/doi/pdf/10.1177/2056305119891220 Erişim tarihi: 5 Haziran 2020. https://doi.org/10.1177/2056305119891220

Rigel, N. (2000). Ileti tasarımında haber. Der Yayınları.

Schoeller, M. G. (2014). "Explaining political leadership: Germany's role in shaping the fiscal compact". 1-23. https://papers.ssrn.com/sol3/papers.cfm?abstract_id=2466334 Erişim tarihi: 5 Haziran 2020. https://doi.org/10.2139/ssrn.2466334

Sütçü, C., Düvenci, A. \& Aytekin, Ç. (2013). "Türkiye'deki siyasal yaşamda sosyal medya: Siyasal partilerin kullanım düzeylerine ilişkin bir araştırma". Yeni Medya'da demokrasi. A. Algül, N. Üçer. (Ed.). Literatürk Yayınları. 165-204.

Turgut, S. (2013). Yeni medya. Destek Yayınları.

Türkiye'de darbe tartışması nasıl başladı, kim ne söyledi?. (2020, 11 Mayıs). https://www.bbc.com/turkce/haberler-turkiye-52625627 Erişim tarihi: 9 Eylül 2020. 
Türkiye Bilimler Akademisi. (2020). Covid-19 pandemi değerlendirme raporu. Türkiye Bilimler Akademisi Yayınları. http://www.tuba.gov.tr/files/yayinlar/raporlar/Covid-19\%20Raporurevize.pdf Erişim tarihi: 31 Mayıs 2020. https://doi.org/10.22520/tubaar.2017.20

van Dijck, J. \& Poell, T. (2013). "Understanding social media logic". 1-14. https://papers.ssrn.com/sol3/papers.cfm?abstract_id=2309065 Erişim tarihi: 5 Haziran 2020. 